\title{
Supramolecular self-assembly of a new multi-conformational Schiff base through hydrogen bonds: Crystal structure, spectroscopic and theoretical investigation
}

\author{
Mariana Rocha ${ }^{\text {a }}$, A. Di Santo a ${ }^{\text {, G.A. Echeverría }}{ }^{\text {b, }}{ }^{\text {, O.E. Piro }}{ }^{\text {b, } 1}$, F.D. Cukiernik ${ }^{\text {c, }}{ }^{\text {, }}$ \\ S.E. Ulic ${ }^{\text {d, e, }}{ }^{* *}, 1$, Diego M. Gil ${ }^{\text {a, }}{ }^{*, 1}$ \\ a INQUINOA (CONICET-UNT), Instituto de Química Física, Facultad de Bioquímica, Química y Farmacia, Universidad Nacional de Tucumán, San Lorenzo 456, \\ T4000CAN Tucumán, Argentina \\ b Departamento de Física, Facultad de Ciencias Exactas, Universidad Nacional de La Plata e IFLP (CONICET, CCT- La Plata), C.C. 67, 1900 La Plata, Argentina \\ ${ }^{\mathrm{c}}$ DQIAQF/INQUIMAE, Facultad de Ciencias Exactas y Naturales, Universidad de Buenos Aires, Pabellón II, Ciudad Universitaria, Núñez, C1428EHA CABA, \\ Argentina \\ d CEQUINOR (CONICET-UNLP), Facultad de Ciencias Exactas, Universidad Nacional de La Plata, 47 and 115, 1900 La Plata, Argentina \\ e Departamento de Ciencias Básicas, Universidad Nacional de Luján, Rutas 5 y 7, 6700 Luján, Buenos Aires, Argentina
}

\section{A R T I C L E I N F O}

\section{Article history:}

Received 18 August 2016

Received in revised form

20 October 2016

Accepted 23 November 2016

Available online 24 November 2016

\section{Keywords:}

Schiff bases

Crystal structure

Quantum chemical calculations

IR and Raman spectroscopy

Hirshfeld surface analysis

Mesomorphic properties

\begin{abstract}
A B S T R A C T
The compound 4-(4-dimethylaminobenzylidene)aminoacetophenone was synthesized by condensation of 4-aminoacetophenone and 4-(dimethylamino) benzaldehyde in ethanol. This compound was characterized by CG-MS, infrared, Raman, UV-Vis, ${ }^{1} \mathrm{H}$ and ${ }^{13} \mathrm{C}$ NMR spectroscopy. The crystal structure was solved by single-crystal X-ray diffraction methods. The crystallographic data reveals that there are four independent molecules per asymmetric unit, that mainly differ from one another in rotations around the $\sigma$-bond of the azomethine $\mathrm{N}$-atom with the phenyl ring. A detailed analysis of the intermolecular interactions in the four conformers of the compound has been performed using Hirshfeld surfaces and their associated two-dimensional fingerprint plots. The optimized geometrical parameters and calculated spectroscopic features obtained by quantum chemical calculations at B3LYP method show a very good agreement with the experimental data. Moreover, Natural Bond Orbital (NBO) analysis confirms the strong hyper-conjugative $\mathrm{LP} \mathrm{N}(\mathrm{n} 1) \rightarrow \sigma^{*} \mathrm{C}(\mathrm{n} 9)-\mathrm{H}$ interaction between the lone pair located in the $\mathrm{N}$ atom of the azomethine group and the $\mathrm{C}-\mathrm{H}$ bond. Liquid crystalline properties of the Schiff base were studied by differential scanning calorimetry (DSC), polarizing optical microscopy (POM) and Powder Xray diffraction techniques. Mesomorphic behaviour was observed in this unsymmetrical azomethine. Based on POM and DSC measurements, the hexatic Smetic B phase was detected.
\end{abstract}

(c) 2016 Elsevier B.V. All rights reserved.

\section{Introduction}

Azomethines, generally known as Schiff bases, were first reported in 1864 by Hugo Schiff [1]. They can be obtained by condensation of primary amines with carbonyl compounds (aldehydes or ketones). The common structural feature of these

\footnotetext{
* Corresponding author.

** Corresponding author. CEQUINOR (CONICET-UNLP), Facultad de Ciencias Exactas, Universidad Nacional de La Plata, 47 and 115, 1900, La Plata, Argentina.

E-mail addresses: sonia@quimica.unlp.edu.ar (S.E. Ulic),dmgil@fbqf.unt.edu.ar (D.M. Gil)

1 Members of the Research Career of CONICET.
}

compounds is the azomethine functional group with the general formula $\mathrm{RHC}=\mathrm{N}-\mathrm{R}_{1}$, where $\mathrm{R}$ and $\mathrm{R}_{1}$ are alkyl, aryl, cycloalkyl or heterocyclic groups. Benzylidene anilines are an important class of Schiff bases which have been widely used in coordination, medicinal and biological chemistry and therefore experimental and theoretical studies on their molecular and crystal structure have been of considerable interest. Generally, Schiff bases exhibit a wide array of biological activities, including anti-fungal, anti-bacterial, anti-malarial, anti-proliferative, anti-inflammatory, anti-viral and anti-pyretic properties [2,3]. Furthermore, imine or azomethine group is present in various natural, naturally derived and nonnatural compounds, and the $-\mathrm{C}=\mathrm{N}-$ moiety has proved to be critical for biological activity [4-6]. Schiff bases are also of interest 
as corrosion inhibitors, catalyst carriers, thermo-stable materials, metal complexion agents and in biological systems they have a wide range of applications, such as dyes and pigments [7-11]. A large number of Schiff bases and their metal complexes have been investigated because their ability to bind reversibly to oxygen [12], catalytic activity in the hydrogenation of olefins [13,14], photochromic properties [15] and complexing ability towards some toxic metals [16].

Schiff bases containing 4-(dimethyamino)benzaldehyde, as precursor, are reported in literature [17-22] and some were used as ligand in coordination compounds [17] and as novel third order non-linear optical materials [18-21]. Recently, Fang et al. have reported the relationship between the molecular conformation and spectroscopic properties of unsymmetrical 4,4'-disubstituted benzylidene anilines [23]. The Schiff bases are also used in the design of liquid crystals and prompted research in establishing structureproperty relationships, which are elemental in selecting molecular modifications for the synthesis of mesogens with desirable properties $[24,25]$. Indeed, a high number of liquid crystals based on Schiff bases have been reported, either as organic compounds or as ligands of metal-containing mesogens (metallomesogens) [26]. In most cases, calamitic mesophases, either nematic (N) or smectic $(\mathrm{Sm})$ have been detected for Schiff bases bearing long aliphatic chains as terminal substituents. Reports on mesogenic character with short terminal aliphatic chains or small non-aliphatic substituents remain scarce. Particularly, for the compound under study, the ability of the terminal dimethylamino group to act as a charge-transfer donor in the formation of conjugative interactions and contributing to the polarizability of the molecule, prompted several recent studies on the potential applications of Schiff bases containing dimethylamino group as liquid crystals [27,28].

In the present work, the synthesis, structure, conformational and spectroscopic analysis of 4-(4-dimethylaminobenzylidene) aminoacetophenone are reported. The compound was characterized by ${ }^{1} \mathrm{H}$ and ${ }^{13} \mathrm{C}$ Nuclear Magnetic Resonance (NMR), Infrared (IR), Raman, UV-Vis and fluorescence spectroscopy, GC-MS spectrometry, thermo-gravimetric and differential thermal (TG and DTA) analysis and differential scanning calorimetry (DSC). These measurements were complemented with quantum chemical calculations using the DFT/B3LYP method and different basis sets. Interestingly, the presence of non classical intermolecular interactions, mainly such as $\mathrm{H} \cdots \mathrm{H}$ and $\mathrm{C} \cdots \mathrm{H}$, allow the stabilization of four independent conformers in the unit cell, which were detected by X-ray diffraction methods. A detailed analysis of the intermolecular interactions on the crystal packing was evaluated using Hirshfeld surface analysis. The stability of the different observed conformations was estimated by means of the NBO analysis. The liquid crystalline properties were also evaluated.

\section{Materials and methods}

\subsection{Synthesis of 4-(4-dimethylaminobenzylidene) aminoacetophenone}

A solution of 4-(dimethylamino) benzaldehyde (1) and 4aminoacetophenone (2) in absolute ethanol in molar ratio 1:1 was heated under reflux for $12 \mathrm{~h}$. The reaction mixture was then cooled and the obtained yellow solid was isolated by filtration and washed with cold ethanol. The solid was re-crystallized from hot ethanol to give yellow fine crystals. The purity of the substance was checked by ${ }^{1} \mathrm{H}$ and ${ }^{13} \mathrm{C}$ NMR, IR and Raman spectroscopy and GCMass spectrometry. Single crystals of suitable quality for X-ray diffraction analysis were obtained by slow evaporation of the solution in methanol.

Scheme 1 shows the mentioned reaction.
2.1.1. 4-(4-dimethylaminobenzylidene)aminoacetophenone (3)

Yield: 70\%; MP: $178{ }^{\circ} \mathrm{C} ;{ }^{1} \mathrm{H}$ NMR $\left(200 \mathrm{MHz}, \mathrm{CDCl}_{3}\right): \delta=8.35$ (s, $\mathrm{H}-\mathrm{C}=\mathrm{N}$ ), 8.02 (d, H-8, H-9), 7.82 (d, H-24, H-26), 7.26 (d, H-7, H10), 6.78 (d, H-28, H-29), $3.12\left(\mathrm{~s}, \mathrm{~N}\left(\mathrm{CH}_{3}\right)_{2}\right), 2.65\left(\mathrm{~s}, \mathrm{COCH}_{3}\right) .{ }^{13} \mathrm{C} \mathrm{NMR}$ (50.3 MHz, $\left.\mathrm{CDCl}_{3}\right): \delta=197$ (C-11), 161 (C-17), 157 (C-27), 153 (C-6), 134 (C-3), 130 (C-22, C-21, C-2, C-4), 129 (C-20), 121 (C-1, C-5), 112 (C-23, C-25), 40 (C-31,C-35), 27 (C-13) ppm (For atoms numbering scheme see Fig. 1). EIMS: $m / z$ (rel. int.) $\left[\mathrm{M}^{+}\right] 266$ (90), 251 (75), 223 (40), 145 (15), 120 (5). Experimental spectra are presented in Supplementary Information.

\subsection{Instrumentation}

\subsubsection{NMR spectra}

The ${ }^{1} \mathrm{H}(200 \mathrm{MHz})$ and ${ }^{13} \mathrm{C}(50.3 \mathrm{MHz})$ NMR spectra were recorded on a Varian Unity 200 spectrometer. The sample was dissolved in $\mathrm{CDCl}_{3}$ in a $5 \mathrm{~mm}$ NMR tube. Chemical shifts $(\delta)$ for ${ }^{1} \mathrm{H}$ and ${ }^{13} \mathrm{C}$ NMR spectra are given in ppm relative to TMS $(\delta=0 \mathrm{ppm})$ and are referenced by using the residual non-deuterated solvent signal. Coupling constants, $J$, are reported in $\mathrm{Hz}$, being the singlet and doublet identified as $s$ and $d$, respectively.

\subsubsection{GC-MS spectrometry}

The analysis was carried out using a Model Trace GC Ultra gas chromatography Thermo electron coupled to a Polaris Q mass spectrometer with an ion-trap analyzer using a DB-5 capillary column. Split-less injection $(10 \mu \mathrm{L})$ was used for this study, the initial temperature of $60{ }^{\circ} \mathrm{C}$ was kept for $4 \mathrm{~min}$, and then was increased at a rate of $15^{\circ} / \mathrm{min}$ to reach $200^{\circ} \mathrm{C}$. The final temperature was maintained for $6 \mathrm{~min}$ and the total run time was $13.8 \mathrm{~min}$, using Helium as carrier gas. The mass spectrometer was operated in the electronic ionization scan mode (range, $m / z$ : 40-450). Quantification of the peaks was based on peak area.

\subsubsection{UV-visible spectroscopy}

The spectra of the substance in dimethylformamide (DMF) and chloroform $\left(10^{-4} \mathrm{M}\right)$ were recorded on a Beckman/DU 7500 spectrophotometer in the spectral region of $200-800 \mathrm{~nm}$ using a quartz cell (10 $\mathrm{mm}$ optical path length).

\subsubsection{Fluorescence spectra}

Fluorescence measurements were recorded on a Perkin-Elmer LS-50B luminescence spectrometer (Beaconsfield, England) equipped with a quartz cell of $1 \mathrm{~cm}$ path length, a pulsed xenon lamp (half peak height $<10 \mathrm{~m} \mathrm{~s}, 60 \mathrm{~Hz}$ ), an R928 photomultiplier tube. Both excitation and emission slits were $10 \mathrm{~nm}$ wide.

\subsubsection{IR and Raman spectroscopy}

The IR absorption spectra of the solid were recorded in $\mathrm{KBr}$ pellets, with a resolution of $2 \mathrm{~cm}^{-1}$ on a FTIR Perkin Elmer GX1 in the 4000 and $400 \mathrm{~cm}^{-1}$ range. The Raman spectrum of the solid was measured in the $3500-50 \mathrm{~cm}^{-1}$ interval with a Thermoscientific DXR Raman microscope. The Raman dispersion data were collected using a diode-pump, solid state laser of $532 \mathrm{~nm}$ (at $5 \mathrm{~cm}^{-1}$ spectral resolution), a confocal aperture of $25 \mu \mathrm{m}$ pinhole and $10 \times$ objective. The sample was placed on gold-coated sample slide. To improve the signal to noise ratio, 30 spectral scans of $2 \mathrm{~s}$ each were accumulated during the measurements with the laser power maintained at $10 \mathrm{~mW}$.

\subsubsection{Thermal analysis}

Thermo-gravimetric (TGA) and differential thermal analysis (DTA) measurements were performed with a Shimadzu DTG-60 thermo-balance in the temperature range of $25-800{ }^{\circ} \mathrm{C}$ at a heating rate of $5{ }^{\circ} \mathrm{C} / \mathrm{min}$ under air flow. 
<smiles>CC(=O)c1ccc(/N=C/c2ccc(N(C)C(=O)OCC(=O)c3ccc(N)cc3)cc2)cc1</smiles>

Scheme 1. Synthesis of the Schiff base.

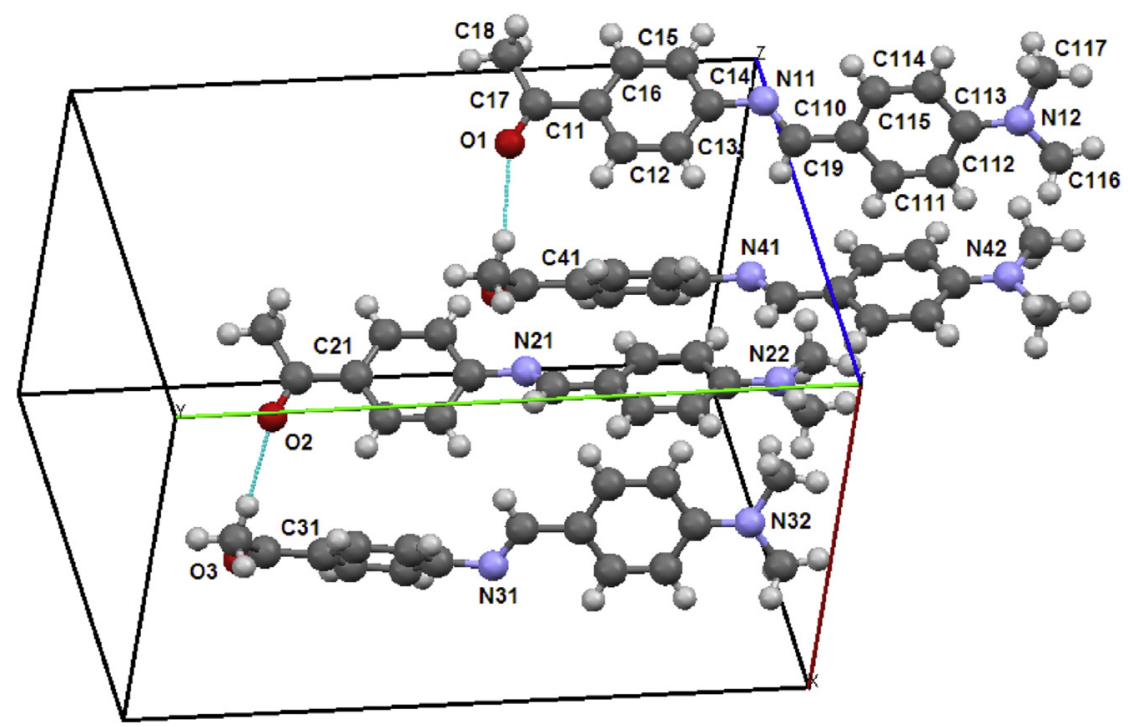

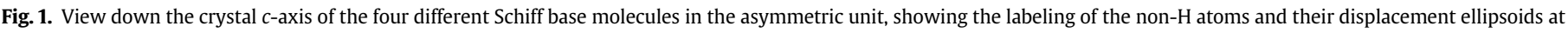

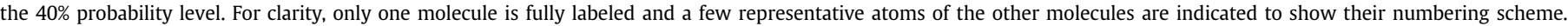

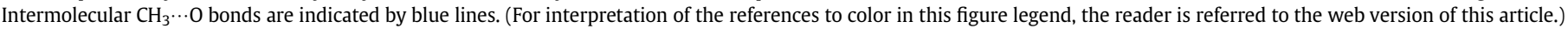

\subsubsection{Mesomorphic studies}

Mesomorphic properties have been studied by means of variable temperature polarizing optical microscopy (POM), Differential Scanning Calorimetry (DSC) and room temperature powder X-ray diffraction (PXRD) techniques. POM measurements have been carried out between crossed polarizers using a Leitz DMRX microscope equipped with a Leitz 1350 hot-stage. DSC experiments have been performed either on a Shimadzu DSC-50 calorimeter or a Perkin Elmer Pyris DSC 6 calorimeter, with heating and cooling rates of 2 or $10{ }^{\circ} \mathrm{C} / \mathrm{min}$, respectively. PXRD measurements on powdered samples were performed on a Siemens D5000 apparatus using the $\mathrm{Cu}-\mathrm{K} \alpha 1$ line $(\lambda=1.5418 \AA$ ) source radiation; the samples were contained on planar glass sample holders.

\subsection{X-ray diffraction data}

The measurements were performed on an Oxford Xcalibur, Eos, Gemini CCD diffractometer with graphite-monochromated CuK $\alpha$ $(\lambda=1.54184 \AA)$ radiation. X-ray diffraction intensities were collected ( $\omega$ scans with $\vartheta$ and $\kappa$-offsets), integrated and scaled with CrysAlisPro [29] suite of programs. The unit cell parameters were obtained by least-squares refinement (based on the angular settings for all collected reflections with intensities larger than seven times the standard deviation of measurement errors) using CrysAlisPro. Data were corrected empirically for absorption employing the multi-scan method implemented in CrysAlisPro.

In a first attempt, it was intended to solve the structure in $P-1$ space group with a standard run of direct methods implemented in SHELXS of the SHELX suite of programs [30]. Though it provided an electron density map which could be interpreted in terms of the expected molecule, however the appearance of spurious peaks mainly at the centers of a honey comb-like structure make it difficult the interpretation of the map in terms of four molecules per asymmetric unit. It is well known that frequently direct methods works better by referring the cell to a non centersymmetric triclinic space group. In fact, a standard run in $P 1$ cell revealed all eight molecules in the unit cell though still showing the honey-comb centering mentioned above. At variance with the $P-1$ run, now the map can be easily interpreted in terms of the molecules atomic constituents and the structural problem reduced to find the shift of the constellation of atoms to refer them to one inversion center of $P-1$ group, then eliminate one of the inversion related set of molecules and finally proceed with the refinement of the remaining ones in the correct center-symmetric space group. The above problems were easily overcome with the recently available SHELXT program (see Ref. [31] and references therein). The new development is a radical departure of standard structure determination procedures where normally the space group is determined first and the crystal structure afterward. Now, with the only prior knowledge (besides cell constants) of the Laue group and the atom species present in the solid:

1) The X-ray diffraction data set is expanded to the subgroup $P 1$ of all space groups where the structure is solved from an initial trial constellation of peaks provided by Patterson superposition methods. This is followed by dual-space recycling to obtain optimal electron density and phases.

2) The phases are first subjected to a center-symmetric test and a measure of the phase error $\left(\alpha_{0}\right)$ is calculated. This should be small for a constellation of atoms that possess an inversion center. 
3) The phases are then employed to determine both the correct space group and the translation necessary to refer the electron density to the proper unit cell origin.

4) The phases are then averaged in every possible space group compatible with the known Laue group and used to calculate improved maps.

5) The integrated electron density around the peaks of the maps is assigned to atomic species and thus the chemical formula is determined.

6) The correct space group and structure solution is selected among the trials on the basis of several figures of merit, including the standard agreement $R 1$-factor, $R_{\text {weak }}$ (average of calculated $E_{\text {calc }}^{2}$ for the $10 \%$ of unique reflections with the smallest observed normalized structure factors $E_{o b s}$ ), and the phase error $(\alpha)$, all of which should be the smallest for the right choose.

Assuming the Laue group $P-1\left(C_{\mathrm{i}}\right)$ and the presence in the solid of $\mathrm{O}, \mathrm{N}$, and $\mathrm{C}$ atomic species, the structure now yielded easily to the above procedure producing a clear and complete electron density map (no spurious peaks) with an essentially correct interpretation of its maxima in terms of the expected non- $\mathrm{H}$ atoms except for the miss assignment of a nitrogen as a carbon atom, a minor problem that probably arises because the closeness in the number of atomic electrons for both elements.

The initial molecular model was refined by full-matrix leastsquares procedure with SHELXL of the SHELX package [30]. Most $\mathrm{H}-$ atoms were found in a Fourier difference map phased on the heavier atoms. However, they were positions on stereo-chemical basis and refined with the riding model. The methyl H-atoms were refined as rigid groups allowed to rotate around their corresponding $\mathrm{C}-\mathrm{C}$ and $\mathrm{N}-\mathrm{C}$ bonds such as to maximize the sum of the observed residual electron density at their calculated positions. As a result all $-\mathrm{CH}_{3}$ groups converged to staggered conformations. Crystal data and structure refinement results are summarized in Table 1. Crystallographic structural data have been deposited at the Cambridge Crystallographic Data Center (CCDC). Any request to the Cambridge Crystallographic Data Center for this material should quote the full literature citation and the reference number CCDC 1411260.

\subsection{Quantum chemical calculations}

Theoretical calculations were performed using the Gaussian 03 program [32]. The employed methods are based on the gradient corrected Density Functional Theory (DFT) with the threeparameter hybrid functional (B3) [33] for the exchange part and the Lee-Yang-Parr (LYP) correlation function [34]. Scans of the potential energy curves were carried out at the B3LYP/6-31G(d,p) approximation. Final optimizations and vibrational frequencies were computed employing the $6-311++G(d, p)$ basis set. The calculated vibrational properties correspond, in all cases, to potential energy minima with no imaginary values for the frequencies. The Potential Energy Distribution (PED) analysis has been calculated using the VEDA4 program [35,36]. Electronic transitions were calculated within the Time-Dependent Density Functional Theory (TD-DFT) [37] in gas phase and taking into account implicitly the solvent effect (DMF and $\mathrm{CHCl}_{3}$ ) at B3LYP/6$311+\mathrm{G}(2 \mathrm{~d}, \mathrm{p})$ approximation. The ${ }^{1} \mathrm{H}$ and ${ }^{13} \mathrm{C}$ NMR chemical shifts were calculated at the B3LYP/6-311+G(2d,p) level by the Gaugeincluding atomic orbital (GIAO) method [38] using the corresponding TMS shielding, calculated at the same level of theory. The Natural Bond Orbital (NBO) analysis for the molecule was performed at B3LYP/6-311++G(d,p) approximation by means the NBO 3.1 program implemented in the Gaussian 03 package.
Table 1

Crystal data and structure refinement results for the Schiff base 4-(4dimethylaminobenzylidene)aminoacetophenone.

\begin{tabular}{|c|c|c|}
\hline & \multicolumn{2}{|l|}{ Compound (3) } \\
\hline Empirical formula & \multicolumn{2}{|l|}{$\mathrm{C}_{17} \mathrm{H}_{18} \mathrm{~N}_{2} \mathrm{O}$} \\
\hline Formula weight & \multicolumn{2}{|l|}{266.33} \\
\hline Temperature & \multicolumn{2}{|l|}{$293(2) \mathrm{K}$} \\
\hline Wavelength & \multicolumn{2}{|l|}{$1.54184 \AA$} \\
\hline Crystal system & \multicolumn{2}{|l|}{ Triclinic } \\
\hline Space group & \multicolumn{2}{|l|}{$P-1$} \\
\hline \multirow[t]{3}{*}{ Unit cell dimensions } & $a=9.9357(4) \AA$ & $\alpha=78.347(4)^{\circ}$ \\
\hline & $b=17.1016(9) \AA$ & $\beta=77.169(4)^{\circ}$ \\
\hline & $c=18.1945(9) \AA$ & $\gamma=76.996(4)^{\circ}$ \\
\hline Volume & \multicolumn{2}{|l|}{$2899.2(2) \AA^{3}$} \\
\hline Z, density (calculated) & \multicolumn{2}{|l|}{$8,1.220 \mathrm{Mg} / \mathrm{m}^{3}$} \\
\hline Absorption coefficient & \multicolumn{2}{|l|}{$0.604 \mathrm{~mm}^{-1}$} \\
\hline $\mathrm{F}(000)$ & \multicolumn{2}{|c|}{1136} \\
\hline Crystal size & \multicolumn{2}{|c|}{$0.354 \times 0.154 \times 0.109 \mathrm{~mm}^{3}$} \\
\hline$\vartheta$-range for data collection & \multicolumn{2}{|c|}{$3.38-71.00^{\circ}$} \\
\hline Index ranges & \multicolumn{2}{|c|}{$-6 \leq \mathrm{h} \leq 12,-20 \leq \mathrm{k} \leq 20,-19 \leq \mathrm{l} \leq 22$} \\
\hline Reflections collected & \multicolumn{2}{|c|}{23254} \\
\hline Independent reflections & \multicolumn{2}{|c|}{$11154[\mathrm{R}(\mathrm{int})=0.0290]$} \\
\hline Observed reflection & \multicolumn{2}{|c|}{7116} \\
\hline Completeness to $\vartheta=71.00^{\circ}$ & \multicolumn{2}{|c|}{$99.6 \%$} \\
\hline Refinement method & \multicolumn{2}{|c|}{ Full-matrix least-squares on $\mathrm{F}^{2}$} \\
\hline Data/restraints/parameters & \multicolumn{2}{|c|}{$11154 / 0 / 733$} \\
\hline Goodness-of-fit on $\mathrm{F}^{2}$ & \multicolumn{2}{|l|}{1.019} \\
\hline Final $R$ indices $[\mathrm{I}>2 \sigma(\mathrm{I})]$ & \multicolumn{2}{|c|}{$\mathrm{R} 1=0.0557, \mathrm{wR}_{2}=0.1423$} \\
\hline $\mathrm{R}$ indices (all data) ${ }^{\mathrm{a}}$ & \multicolumn{2}{|c|}{$\mathrm{R} 1=0.0889, \mathrm{wR}_{2}=0.1715$} \\
\hline Largest diff. peak and hole & \multicolumn{2}{|c|}{0.220 and -0.165 e. $\AA^{-3}$} \\
\hline
\end{tabular}

\subsection{Hirshfeld surface analysis}

Hirshfeld surfaces and their associated 2D fingerprints for all conformers of the Schiff base were generated using CrystalExplorer3.1 program [39]. The $d_{\text {norm }}$ (normalized contact distance) surface and the breakdown of 2D fingerprint plots [40-42] are a novel visual simultaneously representation of all the intermolecular interactions, and they are unique for a given crystal structure and polymorph. Fingerplots provide numerous applications to a wide variety of molecular crystals and intermolecular interactions, including polymorphs systems, as well as crystals with more than one molecule in the asymmetric unit $(Z>1)$. Distances from points on the surface to a nucleus (atom) inside $\left(d_{i}\right)$ and outside $\left(d_{e}\right)$ the mean surface are determined by the differing van der Waals (vdW) radii of atoms, whereby the contact distances $d_{i}$ and $d_{e}$ can be normalized $\left(d_{\text {norm }}\right)$. Therefore, intermolecular interactions (short, moderate, long) in the crystal structure resulting from hydrogen bond donors/acceptors can be visually represented by Hirshfeld surfaces. The $3 \mathrm{D} d_{\text {norm }}$ surfaces are mapped over a fixed color scale of -0.08 au (red) to 0.6 au (blue). The 2D fingerprint plots are displayed by using the standard $0.57-2.7 \AA$ view and including reciprocal contacts, with the $d_{e}$ and $d_{i}$ distance scales showed on the graph axes.

\section{Results and discussion}

\subsection{Crystallographic structural results}

Crystal data and structure refinement results are summarized in Table 1. The compound 4-(4-dimethylaminobenzylidene)aminoacetophenone crystallizes in the triclinic $P-1$ space group with $a=9.9357(4) \AA, b=17.1016(9) \AA, c=18.1945(9) \AA, \alpha=78.347(4)^{\circ}$, $\beta=77.169(4)^{\circ}, \gamma=76.996(4)^{\circ}$, and $Z=8$ molecules per unit cell. Fig. 1 shows the molecular structure of the four independent conformers per asymmetric unit observed in the solid state structure of the compound which have an E conformation about the central 
$-\mathrm{C}=\mathrm{N}-$ bond. These molecules differ from each other mainly in rotations around the $\sigma$-bond of the azomethine $\mathrm{N}$-atom with the phenyl ring (Cn3-Cn4-Nn1-Cn9 torsion angles of $42.1(3)^{\circ},-37.7(3)^{\circ}, 130.3(2)^{\circ}$, and $-140.2(2)^{\circ}$ for $\mathrm{n}=1\left(\mathrm{C}_{\mathrm{I}}\right), 2\left(\mathrm{C}_{\mathrm{II}}\right)$, $3\left(C_{I I I}\right), 4\left(C_{I V}\right)$ conformers, respectively), a fact that reflects the conformational freedom of the molecule around this single bond $[\mathrm{N}-\mathrm{C}(\mathrm{ph})$ distances in the $1.403(3)-1.406(3) \AA$ range $]$. This link contrasts with the much shorter and partially double $\mathrm{N}(\mathrm{azo})=\mathrm{CH}$ bond [ $\mathrm{N}-\mathrm{C}$ distances in the 1.265(3)-1.275(3) Å interval], which is part of an extended $\pi$-delocalization that renders $\mathrm{N}-(\mathrm{CH})-(\mathrm{ph})-$ $\mathrm{N}\left(\mathrm{CH}_{3}\right)_{2}$ skeleton nearly planar. The (ph)-N(CH$)_{2}, \mathrm{~N}-\mathrm{CH}_{3}$ and carbonyl $\mathrm{C}=\mathrm{O}$ bond lengths are in the range of $1.358(3)-1.370(3) \AA$, $1.436(4)-1.452(3) \AA$ and $1.212(3)-1.221(3) \AA$, respectively. Bond distances within the phenyl rings vary from $1.364(3)$ to $1.415(3) \AA$, as expected for the resonant bond structures of these aromatic groups. The corresponding bond lengths, angles and selected dihedral angles for each conformer found in the crystal are given in Table 2, where they are compared with the corresponding computed values at B3LYP/6-311++G(d,p) approximation. All geometrical parameters determined experimentally are presented in the Supplementary Information. The above bond distances are in general agreement with the corresponding reported ones for the closely related 1-(4-\{[(E)-(4-Diethylamino)-2-hydroxyphenyl)methylene]amino\}phenyl)ethanone [43]. The main difference between both structures is the intra-molecular $\mathrm{O}-\mathrm{H} \cdots \mathrm{N}$ hydrogen bond observed for the last compound, which stabilizes the planar molecular conformation around the azomethine group. The crystal packing is also stabilized by $\pi-\pi$ stacking interactions between neighboring molecules [43], which are absent in the title compound.

Besides their mutual interaction through van der Waals forces, the molecules are arranged in a pair of dimers (see Fig. 1) involving molecules $1\left(\mathrm{C}_{\mathrm{I}}\right)$ and $4\left(\mathrm{C}_{\mathrm{IV}}\right)$ and molecules $2\left(\mathrm{C}_{\mathrm{II}}\right)$ and $3\left(\mathrm{C}_{\mathrm{III}}\right)$, where they are linked to each other by weak $\mathrm{CH}_{3} \cdots \mathrm{O}$ bonds $\left[\mathrm{d}(\mathrm{C} 38 \cdots \mathrm{O} 2)=3.550(5) \AA, \quad \angle(\mathrm{C} 38-\mathrm{H} \cdots \mathrm{O} 2)=173.2^{\circ}\right.$ and
$\left.\mathrm{d}(\mathrm{C} 48 \cdots \mathrm{O} 1)=3.584(4) \AA, \angle(\mathrm{C} 48-\mathrm{H} \cdots \mathrm{O} 1)=167.4^{\circ}\right]$. At the same time, the molecules are organized into columns along the crystal $b$ axis. The columns project onto the crystal $a^{*} c^{*}$-plane as a distorted hexagonal, centered wasp net-like, arrangement (see Supplementary Information). As will discussed below, in the SubSection 3.9, DSC and Polarized Optical Microscopy (POM) experiments show, that upon heating, the solid undergoes a crystal $\rightarrow$ liquid crystal (LC) phase transition to an (hexatic) smectic $B$ phase. The crystallographic results suggest the possible structure of the LC phase. In fact, upon increasing temperature, when partial disorder sets in, the system could undergo, by small topological changes, a crystal $\rightarrow$ LC transformation to a smectic phase with a slightly tilted pseudo-hexagonal structure. Further structural studies on the phase transition are in progress and will be reported elsewhere.

\subsection{Structural properties}

The conformational properties of the Schiff base have been investigated through quantum chemical calculations using B3LYP/ $6-31 G(d, p)$ level of approximation. The scan was obtained by minimizing the potential energy in all geometrical parameters by varying the torsion angle around the $\mathrm{C}-\mathrm{N}$ bond, in steps of $10^{\circ}$, in the range of $0-360^{\circ}$. The potential energy curve (see Supplementary Information) shows four minima, two of them located approximately at $40^{\circ}$ and $140^{\circ}$ (global). From the curve, two stable conformations are predicted for the compound, the $C_{I}$ conformer possesses the lowest energy corresponding to the most stable conformation. The relative energy difference between $C_{I}$ and $\mathrm{C}_{\mathrm{II}}$ conformers is predicted to be $0.5 \mathrm{~kJ} \mathrm{~mol}^{-1}$. The minima located at 220 and $325^{\circ}$ correspond to mirror images (enantiomers) of $C_{I}$ and $\mathrm{C}_{\mathrm{II}}$ conformers, respectively.

Furthermore, the geometry of the four conformers detected experimentally by X-ray diffraction methods were fully optimized including frequency calculations at the B3LYP/6-311++G(d,p)

Table 2

Selected structural parameters (calculated and experimental) for the Schiff base 4-(4-dimethylaminobenzylidene)aminoacetophenone.

\begin{tabular}{|c|c|c|c|c|c|c|c|c|}
\hline \multirow[t]{2}{*}{ Parameters $^{\mathrm{a}}$} & \multicolumn{4}{|c|}{ Experimental $^{\mathrm{b}}$} & \multicolumn{4}{|c|}{ Calculated $^{\mathrm{C}}$} \\
\hline & $C_{I}$ & $\mathrm{C}_{\mathrm{II}}$ & $\mathrm{C}_{\text {III }}$ & $C_{I V}$ & $C_{I}$ & $\mathrm{C}_{\text {II }}$ & $\mathrm{C}_{\text {III }}$ & $\mathrm{C}_{\mathrm{IV}}$ \\
\hline \multicolumn{9}{|l|}{ Bond lengths (Å) } \\
\hline Cn16-Nn2 & $1.439(3)$ & $1.448(3)$ & $1.445(4)$ & $1.440(4)$ & 1.456 & 1.455 & 1.455 & 1.455 \\
\hline Cn17-Nn2 & $1.449(3)$ & $1.452(3)$ & $1.436(4)$ & $1.448(4)$ & 1.455 & 1.455 & 1.456 & 1.456 \\
\hline $\mathrm{Nn} 2-\mathrm{Cn} 13$ & $1.364(3)$ & $1.362(3)$ & $1.358(3)$ & $1.370(3)$ & 1.377 & 1.377 & 1.379 & 1.379 \\
\hline $\mathrm{Cn} 9-\mathrm{Cn} 10$ & $1.441(3)$ & $1.442(3)$ & $1.447(3)$ & $1.449(3)$ & 1.454 & 1.455 & 1.455 & 1.455 \\
\hline Cn9-Nn1 & $1.265(3)$ & $1.275(3)$ & $1.272(3)$ & $1.274(3)$ & 1.282 & 1.282 & 1.287 & 1.287 \\
\hline $\mathrm{Nn} 1-\mathrm{Cn} 4$ & $1.405(3)$ & $1.406(3)$ & $1.403(3)$ & $1.406(3)$ & 1.397 & 1.396 & 1.398 & 1.398 \\
\hline $\mathrm{Cn} 1-\mathrm{Cn} 7$ & $1.485(3)$ & $1.488(3)$ & $1.469(3)$ & $1.484(3)$ & 1.493 & 1.493 & 1.493 & 1.493 \\
\hline $\mathrm{Cn} 7-\mathrm{Cn} 8$ & $1.500(4)$ & $1.497(4)$ & $1.499(3)$ & $1.494(4)$ & 1.519 & 1.519 & 1.521 & 1.521 \\
\hline $\mathrm{Cn} 7-\mathrm{On}$ & $1.217(3)$ & $1.212(3)$ & $1.221(3)$ & $1.210(4)$ & 1.219 & 1.219 & 1.226 & 1.226 \\
\hline \multicolumn{9}{|l|}{ Angles() } \\
\hline Cn16-Nn2-Cn17 & $116.9(2)$ & $117.5(2)$ & $116.9(2)$ & $117.3(2)$ & 118.6 & 119.3 & 118.8 & 118.8 \\
\hline Cn10-Cn9-Nn1 & $122.7(2)$ & $123.3(2)$ & $124.3(2)$ & $123.9(2)$ & 123.5 & 123.2 & 123.5 & 123.5 \\
\hline $\mathrm{Cn} 9-\mathrm{Nn} 1-\mathrm{Cn} 4$ & $121.4(2)$ & $119.9(2)$ & $118.6(2)$ & $120.0(2)$ & 120.3 & 120.1 & 120.3 & -120.3 \\
\hline Nn1-Cn4-Cn5 & $118.0(2)$ & $117.5(2)$ & $123.1(2)$ & $123.2(2)$ & 118.3 & 118.0 & 123.1 & -123.1 \\
\hline $\mathrm{Nn} 1-\mathrm{Cn} 4-\mathrm{Cn} 3$ & $123.8(2)$ & $124.5(2)$ & $118.9(2)$ & $118.3(2)$ & 123.1 & 123.4 & 118.2 & 118.2 \\
\hline $\mathrm{Cn} 1-\mathrm{Cn} 7-\mathrm{Cn} 8$ & $118.7(2)$ & $118.2(2)$ & $119.5(2)$ & $118.9(3)$ & 118.8 & 118.8 & 119.1 & 119.1 \\
\hline Cn1-Cn7-On & $120.6(3)$ & $120.9(3)$ & $121.3(2)$ & $121.4(3)$ & 121.0 & 120.9 & 120.9 & 120.9 \\
\hline $\mathrm{Cn} 8-\mathrm{Cn} 7-\mathrm{On}$ & $120.7(3)$ & $120.9(3)$ & 119.2(3) & 119.7(3) & 120.2 & 120.2 & -120.0 & 120.0 \\
\hline \multicolumn{9}{|l|}{ Dihedral angles () } \\
\hline Cn11-Cn10-Cn9-Nn1 & $164.6(2)$ & $-171.9(2)$ & $-2.9(3)$ & $6.0(3)$ & 178.4 & -178.8 & -1.6 & 1.6 \\
\hline Cn15-Cn10-Cn9-Nn1 & $-11.7(3)$ & $7.6(3)$ & $176.1(2)$ & $-174.4(2)$ & 1.4 & 1.1 & 178.1 & -178.0 \\
\hline Cn9-Cn10-Nn1-Cn4 & $179.1(2)$ & $179.8(2)$ & $179.6(2)$ & $-176.5(2)$ & 176.4 & -176.5 & 176.3 & -176.3 \\
\hline $\mathrm{Cn} 9-\mathrm{Nn} 1-\mathrm{Cn} 4-\mathrm{Cn} 3$ & $42.1(3)$ & $-37.7(3)$ & $130.3(2)$ & $-140.2(3)$ & 42.0 & 39.7 & 141.1 & -141.1 \\
\hline Cn9-Nn1-Cn4-Cn5 & $-142.5(2)$ & $143.4(2)$ & $-51.5(3)$ & $-42.2(3)$ & 141 & -143.2 & -42.0 & 42.0 \\
\hline
\end{tabular}

${ }^{a} \mathrm{n}=1,2,3,4$ for $\mathrm{C}_{\mathrm{I}}, \mathrm{C}_{\mathrm{II}}, \mathrm{C}_{\mathrm{III}}$ and $\mathrm{C}_{\mathrm{IV}}$ conformers, respectively.

b Experimental parameters obtained from X-ray diffraction measurements.

c Calculated geometrical parameters at B3LYP/6-311++G(d,p) approximation. 
approximation (See Supplementary Information). The molecule possesses an $E$ conformation determined both experimental and calculated. The 4-(dimethylamino)benzylidene ring is nearly coplanar with the $\mathrm{C}-\mathrm{C}=\mathrm{N}$ chain, whereas the acetophenone ring is twisted significantly. Some conformational discrepancies between the crystal structure and the optimized counterpart were observed in conformer $\mathrm{C}_{\text {III. }}$. The most significant structural differences are found in the orientation of the 4-aminoacetophenone ring (Ring 2). This structural disparity is defined by the following torsion angles $\mathrm{C}(39)-\mathrm{N}(31)-\mathrm{C}(34)-\mathrm{C}(33)$ and $\mathrm{C}(39)-\mathrm{N}(31)-\mathrm{C}(34)-\mathrm{C}(35)$ with experimental values $130.3(2)^{\circ}$ and $-51.5(3)^{\circ}$, respectively for $C_{\text {III. }}$ The computed values at $\mathrm{B} 3 \mathrm{LYP} / 6-311++\mathrm{G}(\mathrm{d}, \mathrm{p})$ level were $141.1^{\circ}$ and $-42.0^{\circ}$, respectively. The angles $\mathrm{C}(\mathrm{n} 3)-\mathrm{C}(\mathrm{n} 5)-\mathrm{N}(\mathrm{n} 1)$ and $\mathrm{N}(\mathrm{n} 1)-$ $C(n 10)-C(n 9)$ are in the range $118.2-123.4^{\circ}$ and $123.2-123.5^{\circ}$, respectively for all conformers. The increase respect to the usual values (122.3 $\AA$ ) [22] should reduce steric repulsions between the azomethine group and the phenyl ring. The observed bond lengths $\mathrm{C}(\mathrm{n} 9)-\mathrm{N}(\mathrm{n} 1)$ are between 1.265 and $1.275 \AA$, indicating a double bond character (calculated values: $1.282-1.287 \AA$ ).

The Natural Bond Orbital (NBO) analysis is an efficient method to evaluate the intra- and intermolecular bonding and interactions. Some relevant interactions between Lewis and non-Lewis orbitals along with their stabilization energies are listed in Table 3. For the Schiff base, the most important interaction is $\mathrm{LP} \mathrm{N}(\mathrm{n} 1) \rightarrow \sigma^{*} \mathrm{C}(\mathrm{n} 9)$ $-\mathrm{H}$ (between the $\mathrm{C}=\mathrm{N}$ azomethine and the $\mathrm{C}-\mathrm{H}$ bond). The stabilization energy associated with this hyper-conjugative interaction is in the range $12.27-12.71 \mathrm{kcal} \mathrm{mol}^{-1}$ for all conformers, and increases the electron population of the $\sigma^{*} \mathrm{C}(\mathrm{n} 9)-\mathrm{H}$ orbital $(0.043 \mathrm{e})$. The calculated energy values for the LP N(n2) $\rightarrow \pi^{*} \mathrm{C}(\mathrm{n} 13)-\mathrm{C}(\mathrm{n} 12)$ interactions ranges between 42.81 and $46.66 \mathrm{kcal} \mathrm{mol}^{-1}$ as shown in Table 3. This strong donor-acceptor overlap can be associated with a resonance structure with a partial double bond character for the $\mathrm{N}(\mathrm{n} 2)-\mathrm{C}(\mathrm{n} 13)$ bond.

\subsection{Hirshfeld surface analyses}

The Hirshfeld surface in the crystal is representative of the region in space where molecules come into contact. Therefore, its analysis gives the possibility of obtaining quantitative insights into the nature of intermolecular interactions in the crystalline state. In order to understand the nature of intermolecular contacts and their quantitative contributions to the crystal packing of the Schiff base, the Hirshfeld surfaces and the associated 2D fingerprint plot were calculated. Fig. 2 shows the surfaces mapped over $\mathrm{d}_{\text {norm }}$ for the four conformers observed in the crystal lattice. As expected, they reveal the close contacts between donors hydrogen bonds and some acceptors, but other close contacts are also evident. For conformer I, the two red regions labeled $\mathbf{1}$ and $\mathbf{2}$ in the $d_{\text {norm }}$ map are attributed

Table 3

Second-order perturbation theory analysis of the Fock matrix for all the observed conformers of 4-(dimethyamino)benzylidene acetophenone calculated at B3LYP/6$311++\mathrm{G}(\mathrm{d}, \mathrm{p})$ approximation.

\begin{tabular}{lllll}
\hline${\text { Interaction (donor } \rightarrow \text { acceptor }^{\mathrm{a}}}^{\mathrm{a}}$ & \multicolumn{4}{l}{$\mathrm{E}(2)^{\mathrm{b}}$, $\mathrm{kcal} \mathrm{mol}^{-1}$} \\
\cline { 2 - 5 } & $\mathrm{C}_{\mathrm{I}}$ & $\mathrm{C}_{\mathrm{II}}$ & $\mathrm{C}_{\mathrm{III}}$ & $\mathrm{C}_{\mathrm{IV}}$ \\
\hline $\mathrm{LP} \mathrm{O}(\mathrm{n} 1) \rightarrow \sigma^{*} \mathrm{C}(\mathrm{n} 1)-\mathrm{C}(\mathrm{n} 7)$ & 20.33 & 20.31 & 19.49 & 19.49 \\
$\mathrm{LP} \mathrm{O}(\mathrm{n} 1) \rightarrow \sigma^{*} \mathrm{C}(\mathrm{n} 7)-\mathrm{C}(\mathrm{n} 8)$ & 21.41 & 21.42 & 20.55 & 20.55 \\
$\mathrm{LP} \mathrm{N}(\mathrm{n} 2) \rightarrow \pi^{*} \mathrm{C}(\mathrm{n} 13)-\mathrm{C}(\mathrm{n} 12)$ & 46.66 & 45.28 & 42.82 & 42.81 \\
$\mathrm{LP} \mathrm{N}(\mathrm{n} 1) \rightarrow \pi^{*} \mathrm{C}(\mathrm{n} 1)-\mathrm{C}(\mathrm{n} 5)$ & 6.32 & 6.30 & 6.68 & 6.68 \\
$\mathrm{LP} \mathrm{N}(\mathrm{n} 1) \rightarrow \sigma^{*} \mathrm{C}(\mathrm{n} 1)-\mathrm{C}(\mathrm{n} 2)$ & 6.10 & 6.00 & 6.22 & 6.22 \\
LP N(n1) $\rightarrow \sigma^{*} \mathrm{C}(\mathrm{n} 9)-\mathrm{H}$ & 12.71 & 12.27 & 12.68 & 12.68 \\
Total & 113.5 & 111.6 & 108.4 & 108.4 \\
\hline
\end{tabular}

${ }^{\mathrm{a}}$ LP indicates the lone pair on the specified atom. See Fig. 1 for atom numbering scheme. $\mathrm{n}=1,2,3,4$ for $\mathrm{C}_{\mathrm{I}}, \mathrm{C}_{\mathrm{II}}, \mathrm{C}_{\mathrm{III}}$ and $\mathrm{C}_{\mathrm{IV}}$, respectively.

$\mathrm{b} E(2)$ is the energy of hyper-conjugative interactions. to $\mathrm{C}-\mathrm{H} \cdots \mathrm{O}$ hydrogen bonds. The remaining visible red region on $d_{\text {norm }}$ surface of $\mathrm{C}_{\mathrm{I}}$ is assigned to $\mathrm{N} \cdots \mathrm{H}-\mathrm{C}$ interactions (labeled 3 ) involving the $\mathrm{N}$ atom from the azomethine group and the hydrogen at the meta position on dimethylaminophenyl ring of conformer $\mathrm{C}_{\mathrm{IV}}$. The pale blue to white spots (labeled 4 ) represent $\mathrm{C} \cdot \mathrm{H}$ contacts associated to $\mathrm{C}-\mathrm{H} \cdots \mathrm{C}$ interactions. The packing of the compound is further controlled by a T-shaped $\mathrm{C}-\mathrm{H} \cdots \pi$ interaction (labeled $\mathbf{5}$ in

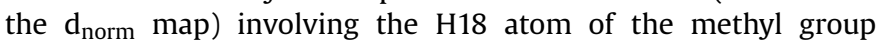
bounded to the carbonyl of $C_{I}$ and the C36-C35 benzene ring [centroid $\mathrm{Cg}(3)$; symmetry: $1-x, 1-y, 1-z]$. The shorter interaction $\mathrm{H} 18 \cdots \mathrm{Cg}(3)$ found was $2.90 \AA . \mathrm{C}-\mathrm{H} \cdots \mathrm{O}$ hydrogen bonds are also present in $\mathrm{C}_{\mathrm{II}}$ conformer, and can be observed as deep-red spots labeled 1 and $\mathbf{2}$ (See Fig. 2). Similar results were obtained for $\mathrm{C}_{\mathrm{III}}$ conformer where the deep-red regions labeled $\mathbf{1}$ and $\mathbf{2}$ are attributed to $\mathrm{C}-\mathrm{H} \cdots \mathrm{O}$ interactions. The red area marked as $\mathbf{1}$ on the $\mathrm{C}_{\mathrm{IV}}$ conformer surface is associated to $\mathrm{C}-\mathrm{H} \cdots \mathrm{O}$ interactions.

Fingerprint plots [40-42] of the main intermolecular contacts for all conformers are shown in Fig. 3. The shortest interactions labeled 1 correspond to the close $\mathrm{H} \cdots \mathrm{H}$ contacts. The $\mathrm{O} \cdots \mathrm{H}$ (labeled 2) and $\mathrm{N} \cdots \mathrm{H}$ (labeled 3) interactions, with sharp pairs of spike centered near a $\left(\mathrm{d}_{\mathrm{e}}+\mathrm{d}_{\mathrm{i}}\right)$ sum of 2.5 and $2.8 \AA$, respectively, correspond to $\mathrm{O} \cdots \mathrm{H}-\mathrm{C}$ and $\mathrm{N} \cdots \mathrm{H}-\mathrm{C}$ hydrogen bonds. A pair of broad wings labeled 4 at around $\left(\mathrm{d}_{\mathrm{e}}+\mathrm{d}_{\mathrm{i}}\right)$ of $2.8 \AA$ is evidence of $\mathrm{C} \cdots \mathrm{H}$ contacts. In accordance with the fingerprint plots, no $\pi-\pi$ stacking interactions were observed. These results are in accordance with reported values for the hydrogen bonding parameters (Supplementary Information). This study emphasizes the importance of Hirshfeld surface and fingerprint plots for a full understanding of non-classical hydrogen bonds and short intermolecular contacts in Schiff bases.

The relative contributions of the intermolecular interactions to the Hirshfeld surface area for all conformers are shown as a histogram (see Supplementary Information). For $C_{I}$ conformer, the $\mathrm{H} \cdots \mathrm{H}$ interactions have the major contribution to the crystal packing (51.4\%) and the $\mathrm{C} \cdots \mathrm{H}$ interactions comprise the $34 \%$ of total Hirshfeld surface area. Some interactions such as $\mathrm{O} \cdots \mathrm{H}$ and $\mathrm{N} \cdots \mathrm{H}$ are also observed with contributions of $8.7 \%$ and $5.1 \%$, respectively. For $\mathrm{C}_{\mathrm{II}}$ and $\mathrm{C}_{\mathrm{IV}}$ conformers, the $\mathrm{O} \cdots \mathrm{H}$ interactions have higher values of contribution compared with those $\mathrm{C}_{\mathrm{I}}$ and $\mathrm{C}_{\mathrm{III}}$ conformers.

\subsection{Vibrational analysis}

The experimental IR and Raman spectra of the compound (solid) are shown in Fig. 4. The assignment of the observed bands was performed based on theoretical calculations (B3LYP/6$311++G(d, p))$ and values reported for related molecules [44-52]. Table 4 displays experimental and calculated frequencies and a tentative assignment of the most important vibration modes. In order to approximate the theoretical values to experimental ones, the scale factor of 0.9608 was used, in accordance with results previously reported $[44,45]$. The simulated IR and Raman spectra are presented in Supplementary Information. Only some characteristic vibration modes of the Schiff base will be discussed.

\subsubsection{Methyl vibrations}

The molecule possesses one methyl group linked to the $\mathrm{C}=\mathrm{O}$ group and two others connected to the amino group. The bands located at 2993, 2946 and $2847 \mathrm{~cm}^{-1}$ in the IR spectrum are assigned to the $\mathrm{CH}_{3}$ asymmetric stretching modes of the methyl groups attached to the nitrogen atom, in good agreement with the computed values (3009, 2966 and $2872 \mathrm{~cm}^{-1}$ ), whereas the Raman spectrum shows only a very weak band at $2926 \mathrm{~cm}^{-1}$. The low intensity band located at $2821 \mathrm{~cm}^{-1}$ in the IR spectrum can be attributed to the $\mathrm{CH}_{3}$ symmetric stretching mode (computed value $2866 \mathrm{~cm}^{-1}$ ), while the $\mathrm{CH}_{3}$ stretching modes of the acetyl group 


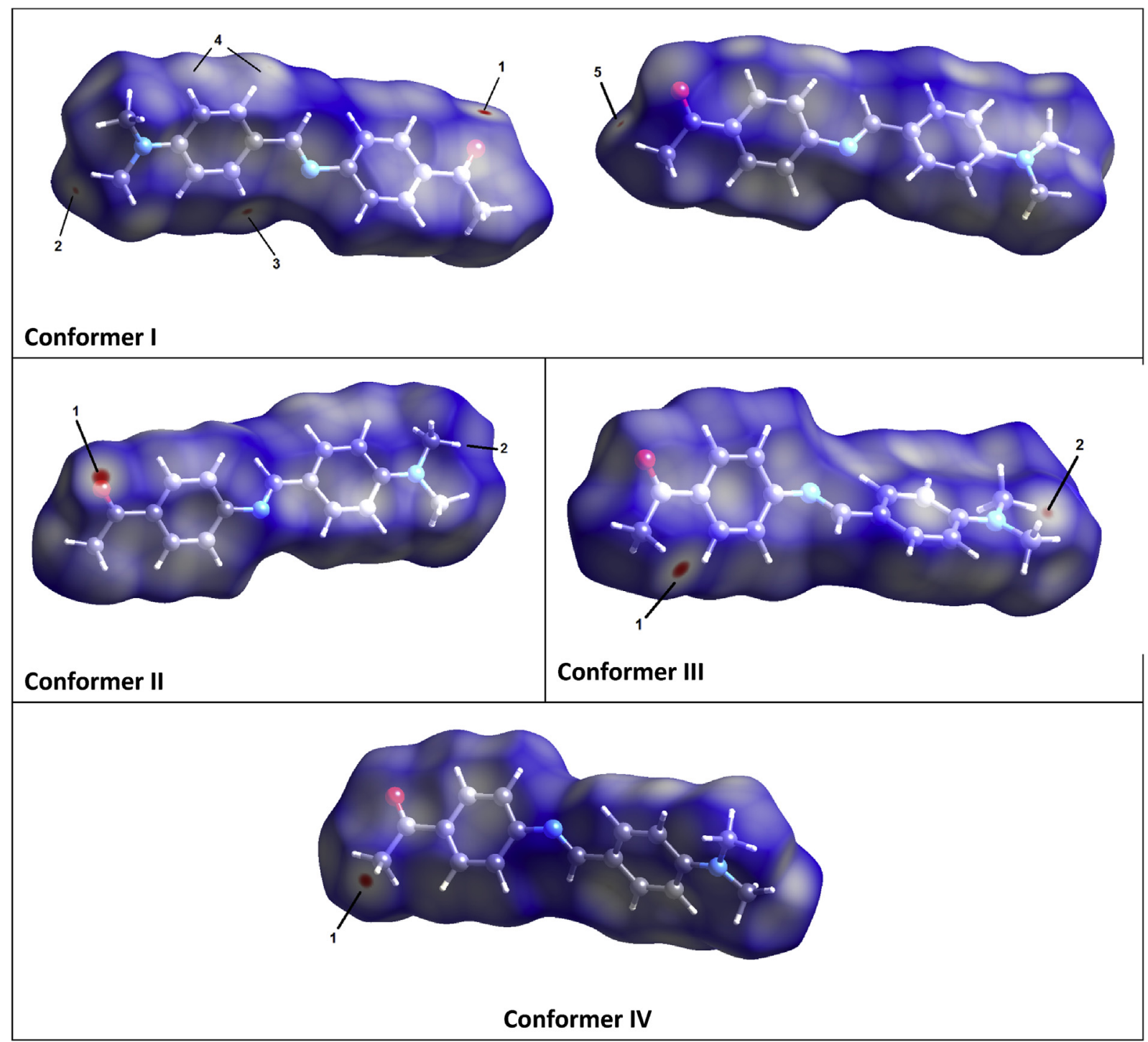

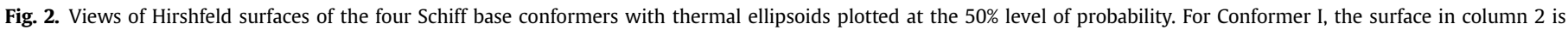
rotated $180^{\circ}$ around the horizontal axis of the plot.

were not observed.

The weak bands located at 1485 and $1447 \mathrm{~cm}^{-1}$ in the IR spectrum (1447 $\mathrm{cm}^{-1}$ in Raman) are assigned to the $\mathrm{CH}_{3}$ asymmetric and symmetric bending modes of the $\mathrm{N}\left(\mathrm{CH}_{3}\right)_{2}$ group, respectively, whereas those for the $\mathrm{CH}_{3}$ linked to the carbonyl group are observed at 1416 and $1365 \mathrm{~cm}^{-1}$, respectively. These values are in accordance with calculated (See Table 4) and previously reported results $[44,46]$.

\subsection{2. $C=O$ vibrations}

The strong IR band located at $1670 \mathrm{~cm}^{-1}\left(1668 \mathrm{~cm}^{-1}\right.$ in Raman) is assigned to the $\mathrm{C}=\mathrm{O}$ stretching mode, while the predicted value is $1665 \mathrm{~cm}^{-1}$. The red shift, relative to other ketones, can be due to the conjugation effect of the $\mathrm{C}=\mathrm{O}$ bond with the aromatic ring. The frequency of the carbonyl stretching mode is not particularly influenced by the ring substituents [47-49]. For the parent Schiff base, 1-(4-((4-bromo-benzylidene)amino)phenyl)ethanone, the $\mathrm{C}=\mathrm{O}$ vibration is observed as a strong IR band at $1668 \mathrm{~cm}^{-1}$ [47].

The medium-intense bands located at 600 and $592 \mathrm{~cm}^{-1}$ in the IR spectrum are assigned to the out-of plane and in-plane $\mathrm{C}=\mathrm{O}$ bending modes, respectively, and are in good agreement with the calculated values (see Table 4).

\subsubsection{Phenyl ring vibrations}

The very weak IR bands located at 3053 and $3031 \mathrm{~cm}^{-1}$ are assigned to the $\mathrm{C}-\mathrm{H}$ stretching modes of both aromatic rings. The $\mathrm{C}-\mathrm{H}$ in-plane bending modes of both rings are attributed to the IR bands at 1316, 1208, 1175 and $1165 \mathrm{~cm}^{-1}(1317,1208,1177$ and $1166 \mathrm{~cm}^{-1}$ in Raman). The $\mathrm{C}-\mathrm{H}$ out-of-plane bending modes are observed at 956,819 and $720 \mathrm{~cm}^{-1}$ in IR and in Raman at 959, 952, $941,825,818$ and $724 \mathrm{~cm}^{-1}$, in accordance with reported $[44,50]$ and calculated values (See Table 4). PED calculations show clearly that these vibrations are coupled with $\mathrm{C}-\mathrm{C}$ stretching modes of the aromatic rings and with other vibration modes of the substituents.

The $\mathrm{C}-\mathrm{C}$ ring stretching modes are prominent in the vibrational spectra of benzene and its derivatives and are assigned in the range of $1650-1200 \mathrm{~cm}^{-1}[44,51]$. For the title molecule, they are attributed to the medium and strong IR bands located at 1607, 1578, 1550, 1436 and $1408 \mathrm{~cm}^{-1}\left(1578,1553,1434\right.$ and $1411 \mathrm{~cm}^{-1}$ in Raman), most of them are coupled. This spectral region is well 


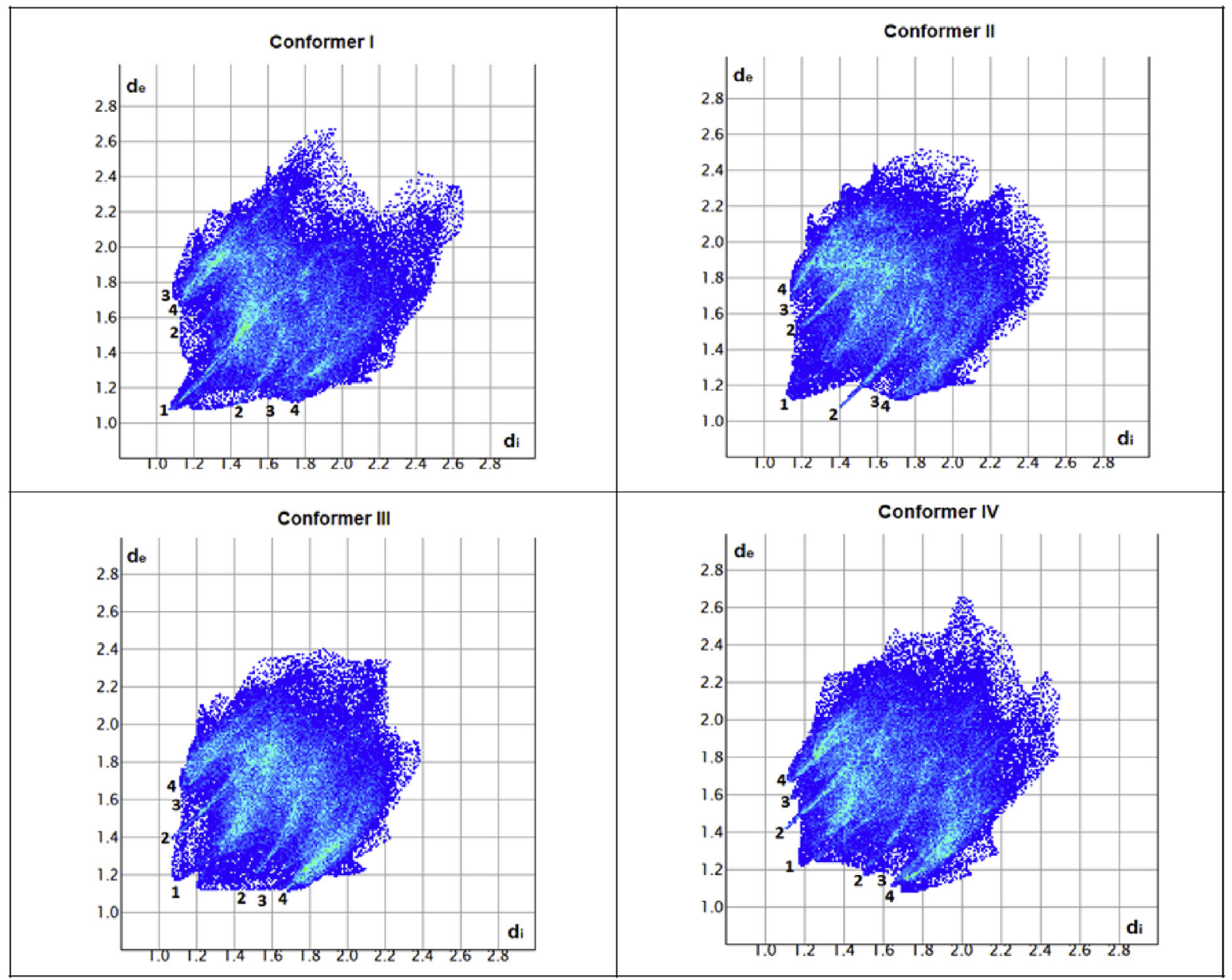

Fig. 3. Fingerprint plots for conformers I, II, III and IV showing (1) $\mathrm{H} \cdots \mathrm{H}$, (2) $\mathrm{O} \cdots \mathrm{H}$, (3) $\mathrm{N} \cdots \mathrm{H}$ and (4) $\mathrm{C} \cdots \mathrm{H}$.

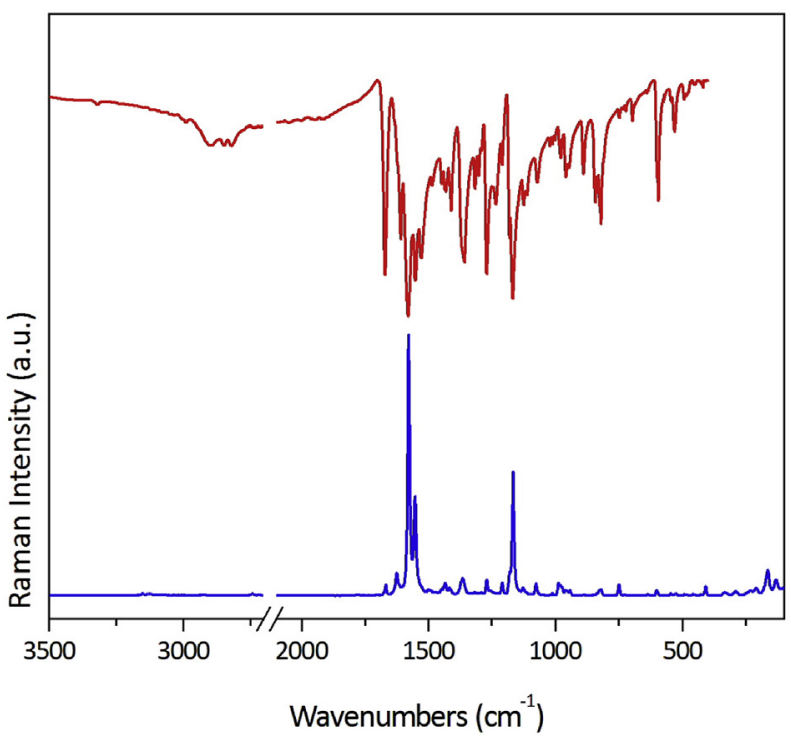

Fig. 4. Experimental IR and Raman spectra (solid) of the Schiff base.

reproduced with quantum chemical calculations with the corresponding frequencies computed to occur at 1649, 1616, 1581, 1471 and $1441 \mathrm{~cm}^{-1}$.

\subsection{4. $C=N$ vibrations}

The azomethine bond is very sensitive to the charge transfer between donor and acceptor groups, and therefore, the $\mathrm{C}=\mathrm{N}$ stretching mode becomes relevant in the synthesis and study of Schiff bases and coordination compounds. The weak band located at $1623 \mathrm{~cm}^{-1}$ in the IR spectrum ( $1624 \mathrm{~cm}^{-1}$ in Raman) is assigned to the $\mathrm{C}=\mathrm{N}$ stretching mode. The calculated value for this mode is predicted at $1679 \mathrm{~cm}^{-1}$ with a contribution of $63 \%$. For related compounds this vibration was reported at $1609 \mathrm{~cm}^{-1}$ and $1582 \mathrm{~cm}^{-}$ $[47,52]$.

The $\mathrm{H}-\mathrm{C}=\mathrm{N}$ in-plane bending mode appears as a strong band located at $1268 \mathrm{~cm}^{-1}$ in the IR spectrum (1269 $\mathrm{cm}^{-1}$ in Raman), and the weak IR band at $956 \mathrm{~cm}^{-1}$ with a Raman counterpart at $959 \mathrm{~cm}^{-1}$ can be assigned to the out-of-plane bending of the $\mathrm{H}-\mathrm{C}=$ $\mathrm{N}$ group.

\section{5. ${ }^{1} \mathrm{H}$ and ${ }^{13} \mathrm{C}$ NMR analysis}

Chemical shifts are recognized as an imperative part of the information contained in NMR spectra. They are valuable for structural interpretation due to their sensitivity to conformational variations. The combined use of NMR experimental spectra and computational simulation methods offers a powerful way to interpret and predict the structure of a large organic molecules and biomolecules. The observed and calculated ${ }^{1} \mathrm{H}$ and ${ }^{13} \mathrm{C}$ NMR chemical shifts for 4-(4-dimethylaminobenzylidene) 
Table 4

Experimental and calculated wavenumbers of the Schiff base and tentative assignment of main fundamental vibrational modes.

\begin{tabular}{|c|c|c|c|c|}
\hline \multicolumn{2}{|c|}{ Experimental } & \multicolumn{2}{|c|}{$\begin{array}{l}\text { Calculated }^{\mathrm{c}} \\
\text { B3LYP/6-311++G(d,p) }\end{array}$} & \multirow[t]{2}{*}{ Approximate description of modes, PED (\%) ${ }^{\mathrm{d}, \mathrm{e}}$} \\
\hline IR (solid) $)^{\mathrm{a}}$ & Raman (solid) $)^{b}$ & Unscaled & Scaled & \\
\hline 3053 vvw & - & 3210 & 3082 & $v \mathrm{C} 23-\mathrm{H}(75)+v \mathrm{C} 21-\mathrm{H}(13)+v \mathrm{C} 25-\mathrm{H}(11)$ \\
\hline $3031 \mathrm{vvw}$ & - & 3180 & 3053 & $v \mathrm{C} 2-\mathrm{H}(76)+v \mathrm{C} 5-\mathrm{H}(18)$ \\
\hline- & - & 3157 & 3157 & $\vee \mathrm{C} 22-\mathrm{H}(97)$ \\
\hline 2993 vw & - & 3134 & 3009 & $v_{\mathrm{a}} \mathrm{CH}_{3}(\mathrm{~N})(96)$ \\
\hline $2946 \mathrm{sh}$ & - & 3090 & 2966 & $v_{\mathrm{a}} \mathrm{CH}_{3}(\mathrm{~N})(100)$ \\
\hline- & $2926(<1)$ & 3048 & 2926 & $v_{\mathrm{a}} \mathrm{CH}_{3}(\mathrm{~N})(86)$ \\
\hline $2898 \mathrm{w}$ & - & 2999 & 2879 & $v \mathrm{C} 17-\mathrm{H}(97)$ \\
\hline $2847 \mathrm{w}$ & - & 2992 & 2872 & $v_{\mathrm{a}} \mathrm{CH}_{3}(\mathrm{~N})(83)$ \\
\hline $2821 \mathrm{w}$ & - & 2985 & 2866 & $v_{a} \mathrm{CH}_{3}(\mathrm{~N})(83)$ \\
\hline $1670 \mathrm{~s}$ & $1668(4)$ & 1734 & 1665 & $v \mathrm{C}=\mathrm{O}(87)$ \\
\hline $1623 \mathrm{w}$ & $1624(9)$ & 1679 & 1612 & $v \mathrm{C} 17=\mathrm{N} 19(63)$ \\
\hline $1607 \mathrm{~m}$ & - & 1649 & 1583 & $v \mathrm{C} 21-23+v \mathrm{C} 22-25(53)+\delta \mathrm{CCH}(11)$ \\
\hline 1578 vs & $1578(100)$ & 1616 & 1551 & $v$ C4-C5 (58) \\
\hline $1550 \mathrm{~s}$ & $1553(38)$ & 1581 & 1518 & $v \mathrm{C} 20-\mathrm{C} 21+v \mathrm{C} 20-\mathrm{C} 22(50)$ \\
\hline $1528 \mathrm{~m}$ & - & 1559 & 1497 & $v \mathrm{C} 27-\mathrm{N} 30(20)+\delta \mathrm{CCH}(26)$ \\
\hline $1485 \mathrm{w}$ & - & 1532 & 1471 & $\delta_{\mathrm{a}} \mathrm{CH}_{3}(\mathrm{~N})(59)+\delta_{\mathrm{a}} \mathrm{CH}_{3}(\mathrm{~N})(21)$ \\
\hline $1447 \mathrm{w}$ & $1447(3)$ & 1488 & 1428 & $\delta_{\mathrm{s}} \mathrm{CH}_{3}(\mathrm{~N})(75)$ \\
\hline $1436 \mathrm{~m}$ & $1434(5)$ & 1471 & 1412 & $v \mathrm{C} 22-25+v \mathrm{C} 21-23(40)+\delta \mathrm{CCH}(27)+\delta_{\mathrm{s}} \mathrm{CH}_{3}(\mathrm{~N})(11)$ \\
\hline $1416 \mathrm{vw}$ & $1417(3)$ & 1467 & 1408 & $\delta_{\mathrm{a}} \mathrm{CH}_{3}(\mathrm{CO})(94)$ \\
\hline $1408 \mathrm{~m}$ & $1411(2)$ & 1441 & 1383 & $v \mathrm{C} 2-\mathrm{C} 1+v \mathrm{C} 5-\mathrm{C} 4(47)+\delta \mathrm{CCH}(29)$ \\
\hline $1365 \mathrm{~s}$ & $1365(7)$ & 1384 & 1329 & $\delta_{\mathrm{s}} \mathrm{CH}_{3}(\mathrm{CO})(83)$ \\
\hline $1316 \mathrm{~m}$ & $1317(1)$ & 1342 & 1288 & $\delta \mathrm{CCH}(40)+v \mathrm{C} 3-\mathrm{C} 4+v \mathrm{C} 1-\mathrm{C} 6(21)$ \\
\hline $1268 \mathrm{~s}$ & $1269(6)$ & 1280 & 1229 & $\delta \mathrm{N} 19-\mathrm{C} 17-\mathrm{H}(16)+v \mathrm{C} 20-\mathrm{C} 17(13)+v \mathrm{C} 6-\mathrm{N} 19(11)$ \\
\hline $1208 \mathrm{w}$ & $1208(5)$ & 1234 & 1185 & $v \mathrm{C} 6-\mathrm{N} 19(24)+\delta \mathrm{CCH}(\mathrm{R} 2)(60)+v \mathrm{C} 4-\mathrm{C} 5(11)$ \\
\hline $1175 \mathrm{sh}$ & $1177(9)$ & 1200 & 1152 & $\delta \mathrm{CCH}(\mathrm{R} 1)(54)$ \\
\hline $1165 \mathrm{~s}$ & $1166(48)$ & 1184 & 1137 & $\delta \mathrm{CCH}(56)$ \\
\hline $1123 \mathrm{w}$ & $1126(3)$ & 1138 & 1092 & $\rho \mathrm{CH}_{3}(\mathrm{~N})(62)+\delta_{\mathrm{a}} \mathrm{CH}_{3}(\mathrm{~N})(27)$ \\
\hline- & $1075(5)$ & 1089 & 1045 & $v \mathrm{C}-\mathrm{C}(\mathrm{R} 2)(31)+v \mathrm{C} 13-\mathrm{C} 11(10)+\delta \mathrm{CH}_{3}(\mathrm{CO})(22)$ \\
\hline $1070 \mathrm{w}$ & - & 1079 & 1036 & $v \mathrm{~N} 30-\mathrm{C} 35+v \mathrm{~N} 30-\mathrm{C} 31(28)+\rho \mathrm{CH}_{3}(\mathrm{~N})(67)$ \\
\hline- & $987(5)$ & 1025 & 984 & $\delta \mathrm{CCC}(\mathrm{R} 2)(69)$ \\
\hline- & $980(4)$ & 1018 & 978 & $\delta \mathrm{CCC}(\mathrm{R} 1)(74)$ \\
\hline $956 \mathrm{w}$ & $959(2)$ & 1006 & 966 & $\gamma \mathrm{C} 17-\mathrm{H}(70)$ \\
\hline- & $952(2)$ & 996 & 956 & $\gamma \mathrm{CCH}-\mathrm{R} 2(78)$ \\
\hline- & $941(2)$ & 984 & 945 & $\gamma \mathrm{CCH}-\mathrm{R} 1(75)$ \\
\hline $887 \mathrm{w}$ & $888(<1)$ & 900 & 864 & $v \mathrm{C}-\mathrm{C}(\mathrm{R} 1)(11)+\delta \mathrm{C} 17-\mathrm{N} 19-\mathrm{C} 6(10)+\delta \mathrm{C} 20-\mathrm{C} 17-\mathrm{N} 19(14)+\gamma \mathrm{CCH}(\mathrm{R} 2)(10)$ \\
\hline $843 \mathrm{w}$ & $848(<1)$ & 847 & 813 & $v \mathrm{C}-\mathrm{C}(\mathrm{R} 1)+v \mathrm{C}-\mathrm{C}(\mathrm{R} 2)(20)+\gamma \mathrm{CCH}-\mathrm{R} 2(14)+\gamma \mathrm{CCH}-\mathrm{R} 1(12)+\delta \mathrm{CCC}(\mathrm{R} 2)(10)$ \\
\hline- & $825(2)$ & 841 & 807 & $\gamma \mathrm{CCH}-\mathrm{R} 2(82)$ \\
\hline $819 \mathrm{~m}$ & $818(3)$ & 832 & 799 & $\gamma \mathrm{CCH}-\mathrm{R} 1(70)$ \\
\hline $747 \mathrm{vw}$ & $748(4)$ & 759 & 729 & $\delta$ CCC-R1 (23) \\
\hline $732 \mathrm{vw}$ & - & 746 & 717 & $\delta$ CCC-R1 (34) \\
\hline $720 \mathrm{vw}$ & $724(<1)$ & 738 & 709 & $\gamma \mathrm{CCH}-\mathrm{R} 1(58)$ \\
\hline $695 \mathrm{w}$ & $697(<1)$ & 704 & 676 & $v \mathrm{C} 11-\mathrm{C} 3(16)+v \mathrm{C} 13-\mathrm{C} 11(14)$ \\
\hline- & $634(<1)$ & 647 & 621 & $\delta \mathrm{CCC}(\mathrm{R} 1)+\delta \mathrm{CCC}(\mathrm{R} 2)(70)$ \\
\hline $600 \mathrm{~m}$ & $600(<1)$ & 605 & 581 & $\gamma \mathrm{C}=\mathrm{O}(41)+\rho \mathrm{CH}_{3}(\mathrm{CO})(10)$ \\
\hline $592 \mathrm{~m}$ & - & 600 & 576 & $v \mathrm{C} 13-\mathrm{C} 11(10)+\delta \mathrm{O} 12-\mathrm{C} 11-\mathrm{C} 13(38)$ \\
\hline- & $546(1)$ & 555 & 533 & $\delta \mathrm{O} 12-\mathrm{C} 11-\mathrm{C} 13(15)+\delta \mathrm{CCC}(\mathrm{R} 1)(15)+\delta \mathrm{C} 31-\mathrm{N} 30-\mathrm{C} 27(10)$ \\
\hline $532 \mathrm{w}$ & $528(2)$ & 539 & 518 & $\gamma \mathrm{CCCC}(\mathrm{R} 1)(58)$ \\
\hline 495 vw & $492(<1)$ & 498 & 478 & $\gamma \mathrm{NCCC}(\mathrm{R} 1)(14)$ \\
\hline $485 \mathrm{vw}$ & $482(<1)$ & 487 & 468 & $\delta \mathrm{CCC}(\mathrm{R} 2)(13)+\gamma \mathrm{CCCC}(\mathrm{R} 2)(10)+\gamma \mathrm{OCCC}(10)$ \\
\hline 453 vvw & $458(<1)$ & 460 & 442 & $\delta \mathrm{C} 31-\mathrm{N} 30-\mathrm{C} 27(24)+\delta \mathrm{C} 13-\mathrm{C} 11-\mathrm{C} 3(4)$ \\
\hline 426 vvw & $427(<1)$ & 436 & 419 & $\delta \mathrm{C} 31-\mathrm{N} 30-\mathrm{C} 27(29)$ \\
\hline- & $409(3)$ & 423 & 406 & $\gamma$ CCCC (R1)(57) \\
\hline- & $333(1)$ & 331 & 318 & $v \mathrm{C} 11-\mathrm{C} 3(15)+\delta \mathrm{O} 12-\mathrm{C} 11-\mathrm{C} 13(16)$ \\
\hline- & $290(2)$ & 288 & 276 & $\delta \mathrm{N} 19-\mathrm{C} 6-\mathrm{C} 1(17)+\tau \mathrm{CCCC}(\mathrm{R} 2)(14)$ \\
\hline- & $232(2)$ & 250 & 240 & $\tau \operatorname{CCCC}(\mathrm{R} 2)(16)+\gamma \mathrm{CCCC}(\mathrm{R} 2)(15)+\delta \mathrm{C} 31-\mathrm{N} 30-\mathrm{C} 27(10)$ \\
\hline- & $210(3)$ & 198 & 190 & $\delta \mathrm{N} 30 \mathrm{C} 27 \mathrm{C} 25(21)+\delta \mathrm{C} 11-\mathrm{C} 3-\mathrm{C} 4(16)+\tau \mathrm{C} 31 \mathrm{H}_{3}(21)$ \\
\hline- & $163(10)$ & 160 & 154 & $\tau \mathrm{C} 31 \mathrm{H}_{3}(38)+\delta \mathrm{N} 30 \mathrm{C} 27 \mathrm{C} 25(11)$ \\
\hline- & $131(6)$ & 110 & 106 & $\tau \mathrm{CH}_{3}(\mathrm{CO})(69)$ \\
\hline- & $90(4)$ & 87 & 84 & $\tau \mathrm{C} 6-\mathrm{N} 19-\mathrm{C} 17-\mathrm{C} 20(16)$ \\
\hline- & $70(6)$ & 76 & 73 & $\tau \mathrm{CCCC}(\mathrm{R} 2)(27)+\tau \mathrm{CH}_{3}(\mathrm{~N})(10)$ \\
\hline
\end{tabular}

a sh, shoulder; s, strong; w, weak; m, medium; vw, very weak; vvw, extremely weak.

b Relative band heights in parentheses.

c Calculated at B3LYP/6-311++G(d,p) level of theory. Scale factor: 0.9608.

d $\nu$ : stretching, $\delta$ : in-plane deformation, $\gamma$ : out-of-plane deformation, $\rho$ : rocking, $\omega$ : wagging, $\tau \omega$ : twisting, $\tau$ : torsion modes.

e See Fig. S7 for the atom numbering. R1: Dimethylaminophenyl ring; R2: Acetophenone ring. 
aminoacetophenone are presented in Table 5 (TMS was used as internal reference). The experimental ${ }^{1} \mathrm{H}$ and ${ }^{13} \mathrm{C}$ NMR spectra are shown in Supplementary Information.

The chemical shifts calculation $(\delta)$ of ${ }^{1} \mathrm{H}$ and ${ }^{13} \mathrm{C}$ was performed with the GIAO method [38], after full geometry optimization with the GAUSSIAN 03 program. Comparing the experimental and theoretical data for protons, a good agreement is observed with $\Delta=\delta_{\text {exp }}-\delta_{\text {calc }}$ deviation ranging from 0.29 to -0.09 in gas phase and from 0.36 to -0.22 in $\mathrm{CHCl}_{3}$.

The $\Delta$-values found for carbon atoms rise up to $12.0 \mathrm{ppm}$. The greatest discrepancy was found in the prediction of the $\mathrm{C}=\mathrm{N}-\mathrm{C}$ chemical shift; $\Delta=-12.0 \mathrm{ppm},\left(-11,0\right.$ in $\left.\mathrm{CHCl}_{3}\right)$. This fact can be explained taking into account that calculations only consider the inductive effect $(-\mathrm{I})$ that is negative for the corresponding carbon atom, excluding the resonance effect, and consequently the shielding contribution of the nitrogen atom.

\subsection{Thermo-gravimetric and differential thermal analysis (TG-DTA)}

The thermal behaviour of the title compound was evaluated by means of TG and DT analysis (Supplementary Information). The experiment was carried out under air atmosphere at a heating rate of $5^{\circ} / \mathrm{min}$. The molecule resulted stable up to $250{ }^{\circ} \mathrm{C}$ and then thermal decomposition takes place. The high thermal stability of this compound probably arises because the chains are further stabilized in the crystal packing by hydrogen bonds between adjacent molecules as was deduced from the X-ray structure discussed previously. The first step finished at $400{ }^{\circ} \mathrm{C}$ with a decrease in mass of $60.2 \%$ (theoretical value: $58 \%$ ), which is associated with the loss of the phenyl groups. From the DT analysis (see Supplementary Information), two endothermic peaks were observed at 153 and $179^{\circ} \mathrm{C}$, without changes in mass. Both peaks are attributed to phase transitions (see Section 3.9), but the second corresponds to the melting point of the sample. The second step in the thermal decomposition occurs between 415 and $640{ }^{\circ} \mathrm{C}$, with an experimental mass loss of $39.8 \%$ (theoretical value: $42 \%$ ) and corresponds to the complete decomposition of the sample. The DTA curve shows an exothermic peak located at $608{ }^{\circ} \mathrm{C}$, corresponding to the complete degradation of the sample into volatile compounds.

\subsection{Electronic spectra}

The experimental and calculated electronic spectra of the Schiff base in chloroform and dimethylformamide are shown in Fig. 5. The transitions with major contribution are shown in Table 6, and only

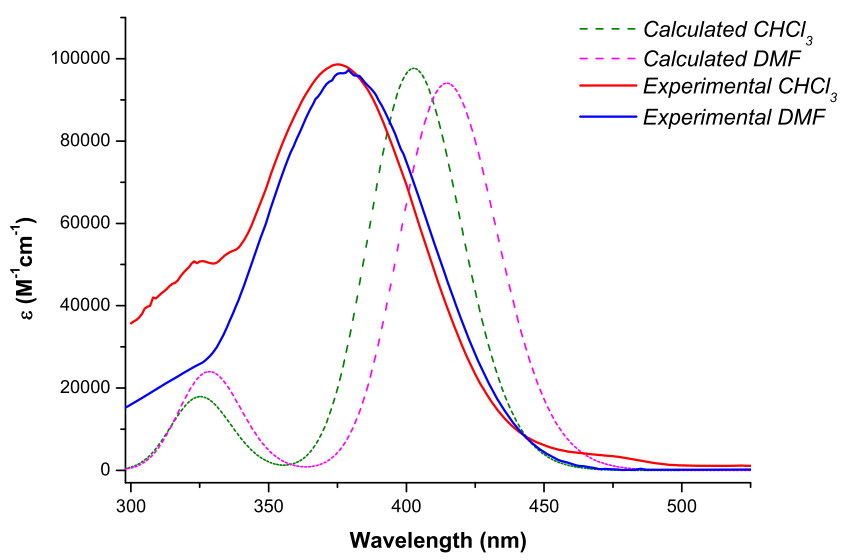

Fig. 5. Experimental and calculated (B3LYP/6-311+G(2d,p)) UV-visible spectra for Schiff base solutions in $\mathrm{CHCl}_{3}$ and DMF.

the dominant excitations (chosen in accordance with their oscillator strength) are used to assign the observed bands. Based on these results, it can be concluded that the correlation between them is a good.

The electronic spectrum in $\mathrm{CHCl}_{3}$ presents a band located at $375 \mathrm{~nm}$ (calculated: $403 \mathrm{~nm}$ ) attributed to a dominant one-electron transition, with $\pi \rightarrow \pi^{*}$ character (see Supplementary Information), from HOMO to LUMO orbitals (98\% of contribution). The absorption observed at $335 \mathrm{~nm}$ is assigned to the HOMO-2 $\rightarrow$ LUMO excitation, with minor contribution of HOMO-2 $\rightarrow$ LUMO +1 transition and the band at $323 \mathrm{~nm}$ corresponds to the HOMO-1 $\rightarrow$ LUMO excitation. The behaviour of the Schiff base in DMF resulted similar and these results are in accordance with the computed values reported in Table 6 .

The frontier molecular orbitals mainly involved in the electronic transitions used to assign the observed bands are depicted in Supplementary Information. The HOMO corresponds to a $\pi$ bonding system localized over phenyl groups and the non-bonding character of the oxygen and both nitrogen atoms. The HOMO-1 involves a $\pi$-bonding system localized over both phenyl rings and a p-type orbital strongly located on the $\mathrm{N}$ atoms. HOMO-2 contains $\pi$ bonding electronic density located in the phenyl ring (R2) and a $p$ system over acetyl group. Both LUMO and LUMO +1 orbitals exhibit $\pi$ anti-bonding character delocalized over both phenyl rings and non-bonding character of nitrogen, oxygen and carbon atoms of methyl groups.

Table 5

Comparison between experimental and B3LYP calculated NMR chemical shifts (in ppm) for 4-(4-dimethylaminobenzylidene)aminoacetophenone.

\begin{tabular}{|c|c|c|c|c|c|c|c|c|}
\hline & \multirow[t]{2}{*}{ Exp. $^{a}$} & \multirow[t]{2}{*}{$\mathrm{J}^{\mathrm{c}}$} & \multicolumn{2}{|c|}{ B3LYP/6-311+G(2d,p) $)^{b}$} & & \multirow[t]{2}{*}{ Exp. } & \multicolumn{2}{|c|}{ B3LYP/6-311+G(2d,p) $)^{b}$} \\
\hline & & & Gas Phase & $\mathrm{CHCl}_{3}$ & & & Gas Phase & $\mathrm{CHCl}_{3}$ \\
\hline $\mathrm{N}-\mathrm{CH}_{3}$ & $3.12(\mathrm{~s})$ & - & $3.01(0.11)$ & $3.08(0.04)$ & $\mathrm{C} 23, \mathrm{C} 25$ & 112 & $114(-2.00)$ & $114(-2.00)$ \\
\hline $\mathrm{C}(\mathrm{O})-\mathrm{CH}_{3}$ & 2.65 (d) & - & $2.46(0.19)$ & $2.58(0.07)$ & $\mathrm{C} 1, \mathrm{C} 5$ & 121 & $121(0.00)$ & $119(2.00)$ \\
\hline $\mathrm{H} 28, \mathrm{H} 29$ & $6.78(d)$ & 8.96 & $6.75(0.03)$ & $6.84(-0.06)$ & $\mathrm{C} 20$ & 129 & $130(-1.00)$ & $128(1.00)$ \\
\hline $\mathrm{H} 7, \mathrm{H} 10$ & $7.26(\mathrm{~d})$ & - & $7.27(-0.01)$ & $7.38(-0.12)$ & $\mathrm{C} 22, \mathrm{C} 21$ & 130 & $136(-6.00)$ & $136(-6.00)$ \\
\hline $\mathrm{H} 24, \mathrm{H} 26$ & $7.82(d)$ & - & $7.88(-0.06)$ & $8.1(-0.28)$ & $\mathrm{C} 2, \mathrm{C} 4$ & 130 & $134(-4.00)$ & $137(-7.00)$ \\
\hline $\mathrm{H} 8$ & $8.02(d)$ & - & $8.02(0.00)$ & $8.24(-0.22)$ & $\mathrm{C} 3$ & 134 & $137(-3.00)$ & $137(-3.00)$ \\
\hline $\mathrm{H} 18$ & $8.35(\mathrm{~s})$ & - & $8.44(-0.09)$ & $8.53(-0.18)$ & $\mathrm{C}=\mathrm{N}-\mathrm{C}$ & 153 & $165(-12.0)$ & $164(-11.0)$ \\
\hline H9 & $8.82(d)$ & - & $8.53(0.29)$ & $8.46(0.36)$ & $\mathrm{C} 27$ & 157 & $156(1.00)$ & $157(0.00)$ \\
\hline $\mathrm{C}(\mathrm{O})-\mathrm{CH}_{3}$ & 27 & - & $27(0.00)$ & $28(-1.00)$ & $C=\mathrm{N}$ & 161 & $164(-3.00)$ & $166(-5.00)$ \\
\hline $\mathrm{N}-\mathrm{CH}_{3}$ & 40 & - & $41(-1.00)$ & $41(-1.00)$ & $C(0)$ & 197 & $200(-3.00)$ & $204(-7.00)$ \\
\hline
\end{tabular}

a Multiplicity between parentheses; s: singlet; d: doublet.

b $\Delta=\delta_{\exp }-\delta_{\text {calc }}$ values in parentheses predicted in vacuo and taking into account implicitly the solvent. The standard numbering scheme adopted for atoms labeling is presented in Supplementary Information.

c Coupling constants in $\mathrm{Hz}$. 
Table 6

Calculated and experimental absorption wavelengths $(\mathrm{nm})$ and oscillator strengths for the most significant transitions in 4-(4-dimethylaminobenzylidene) aminoacetophenone.

\begin{tabular}{|c|c|c|c|}
\hline \multicolumn{2}{|c|}{ Wavelength (nm) } & \multirow[t]{2}{*}{ Oscillator strength } & \multirow[t]{2}{*}{ Assignment } \\
\hline Experimental & Calculated $^{\mathrm{a}}$ & & \\
\hline \multicolumn{4}{|l|}{ Chloroform } \\
\hline 375 & 403 & 1.0869 & HOMO $\rightarrow$ LUMO (98\%) \\
\hline 335 & 328 & 0.0248 & $\begin{array}{l}\text { HOMO-2 } \rightarrow \text { LUMO }(74 \%) \\
\text { HOMO-2 } \rightarrow \text { LUMO+1 (16\%) }\end{array}$ \\
\hline 323 & 325 & 0.1755 & $\begin{array}{l}\text { HOMO-1 } \rightarrow \text { LUMO (59\%) } \\
\text { HOMO } \rightarrow \text { LUMO+1 (27\%) }\end{array}$ \\
\hline \multicolumn{4}{|c|}{ Dimethylformamide (DMF) } \\
\hline 378 & 415 & 1.0461 & HOMO $\rightarrow$ LUMO (98\%) \\
\hline 320 & 330 & 0.2004 & $\begin{array}{l}\text { HOMO -1 } \rightarrow \text { LUMO (48\%) } \\
\text { HOMO } \rightarrow \text { LUMO+1 (27\%) }\end{array}$ \\
\hline- & 324 & 0.0734 & HOMO-2 $\rightarrow$ LUMO (65\%) \\
\hline
\end{tabular}

a Calculated at B3LYP/6-311+G(2d,p) approximation.

\subsection{Fluorescence spectra}

4-(4-dimethylaminobenzylidene)aminoacetophenone was checked for fluorescence, even though some information was found in the literature [53] and the emission spectrum excited at $430 \mathrm{~nm}$ $\left(\lambda_{\text {exc }}\right)$ is shown in Fig. 6 . The broad fluorescence band extends from 450 to $650 \mathrm{~nm}$ with the maximum located at $507 \mathrm{~nm}$. Taking into account the UV absorption spectrum, the emission takes place in a region (red-shifted) where there is no absorption, and accordingly no overlapping between both signals was observed. This could be due, probably, to differences in the geometry of the excited and ground states.

To determine the influence of concentration on the fluorescence, moles of the Schiff base were added to the initial solution in $\mathrm{CH}_{3} \mathrm{CN}\left(8.2510^{-4} \mathrm{M}\right)$. As observed, the fluorescence raised to the third addition $(3 \times 16.3$ nmoles added $)$, then began to go down up to $(5 \times 16.3$ nmoles added $)$ and subsequently an erratic behaviour was noted. In principle, the auto-absorption could be discarded since the negligible UV absorption cross-section at the wavelength of fluorescence. Therefore, it could be inferred, at least at an early stage, that the most probable process would be intermolecular interaction to form dimers. This is supported by the observed crystal packing, (see, Fig. 1), in which the molecules are linked through hydrogen bonds as was discussed previously.

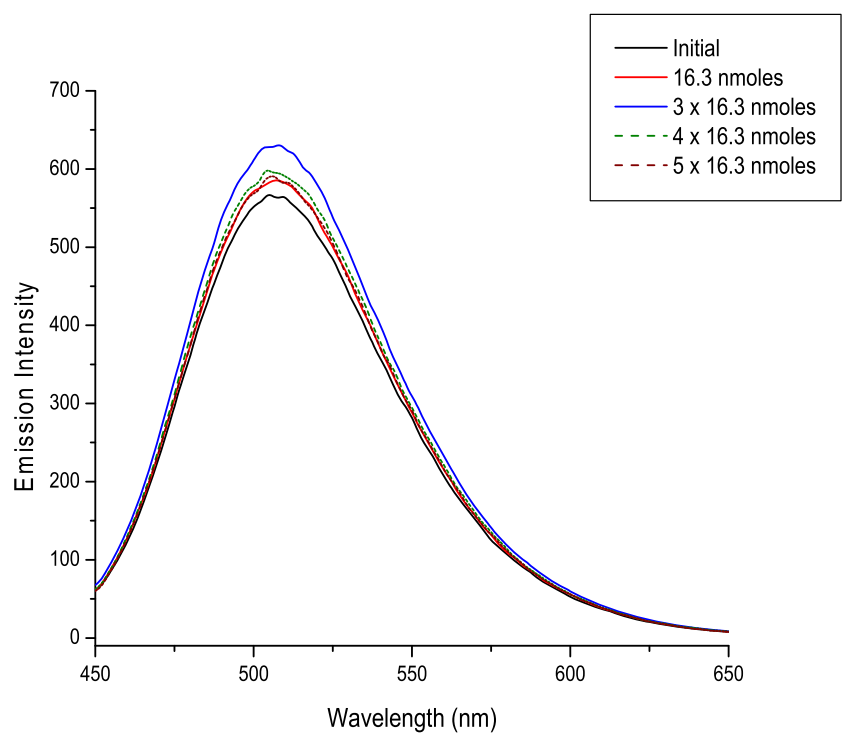

Fig. 6. Fluorescence spectra of the Schiff base in $\mathrm{CH}_{3} \mathrm{CN}$ excited at $430 \mathrm{~nm}$.

\subsection{Mesomorphic behaviour}

DSC experiments performed at $2 \% \mathrm{~min}$ (see Fig. 7) showed two endothermic peaks on heating: the first one from 149 to $153{ }^{\circ} \mathrm{C}$ $\left(\Delta \mathrm{H}=3 \mathrm{~kJ} \mathrm{~mol}^{-1}\right)$; the second one from 175 to $177{ }^{\circ} \mathrm{C}$ $\left(\Delta \mathrm{H}=27 \mathrm{~kJ} \mathrm{~mol}^{-1}\right)$. On cooling, their exothermic counterparts were observed at lower temperatures: 134 to $131^{\circ} \mathrm{C}\left(\Delta \mathrm{H}=-27 \mathrm{~kJ} \mathrm{~mol}^{-1}\right)$ and 36 to $32{ }^{\circ} \mathrm{C}\left(\Delta \mathrm{H}=-1 \mathrm{~kJ} \mathrm{~mol}^{-1}\right)$. The same values have been obtained in subsequent heating/cooling cycles; moreover, the powder XRD pattern recorded at room temperature on a sample heated in the DSC up to the end of the second endothermic peak agreed (except for the relative intensities of some peaks) with that corresponding to a virgin sample.

POM observations showed subtle texture changes at $c a .150{ }^{\circ} \mathrm{C}$; at $180{ }^{\circ} \mathrm{C}$ the sample cleared to the isotropic state (fluid opaque texture). On cooling, a well defined fan-shaped + focal-conic texture has been detected below $135^{\circ} \mathrm{C}$. This texture, characteristic of smetic phases, is displayed in Fig. 7. Mosaic textures have been observed in other cooling cycles. Fan-shaped textures are often associated to SmA, SmC or SmB mesophases; mosaic textures are more typical of SmB phases. Moreover, transformations from fanshaped into mosaic textures after annealing for long time have been reported as characteristic of SmB phases [54]. The relative values of the enthalpy changes associated to both phase transitions ( $\Delta \mathrm{H}$ for the crystal to Sm transition lower than that of the Sm to isotropic transition) also point to an ordered (hexatic) SmB phase.

Schiff bases have been widely used in the field of liquid crystals. A search in the LiqCryst5.1 database [55] retrieved 10184 entries for the specific core under study $(-\mathrm{Ph}-\mathrm{CH}=\mathrm{N}-\mathrm{Ph}-$ ) from aprox. 100000 total cases. In most cases, mesogenic compounds involve long aliphatic chains in at least one of the two terminal positions. Most of the compounds exhibiting the $-\mathrm{Ph}-\mathrm{CH}=\mathrm{N}-\mathrm{Ph}-$ core and "small" substituents in the terminal positions (i.e. halogen atoms groups, nitro groups, alkoxy groups with no more than 2 carbon atoms) are not mesogenic. Among the few examples of mesogenic compounds inside this group, $\mathrm{O}_{2} \mathrm{~N}-\mathrm{Ph}-\mathrm{CH}=\mathrm{N}-\mathrm{Ph}-\mathrm{OCH}_{3} \quad(\mathrm{~N}$ monotropic) and $\mathrm{CH}_{3} \mathrm{O}-\mathrm{Ph}-\mathrm{CH}=\mathrm{N}-\mathrm{Ph}-\mathrm{CONH}_{2}$ (Sm enanthiotropic) deserve to be mentioned. A search restricted to derivatives exhibiting one terminal group identical to those of the compound under study in this work (excluding long-chain compounds) retrieved less than 15 cases of $\mathrm{R}-\mathrm{Ph}-\mathrm{CH}=\mathrm{N}-\mathrm{Ph}-\mathrm{COCH}_{3}$ compounds and about 20 cases of $\left(\mathrm{CH}_{3}\right)_{2} \mathrm{~N}-\mathrm{Ph}-\mathrm{CH}=\mathrm{N}-\mathrm{Ph}-\mathrm{R}$ compounds. Among the first group, the only mesogenic compounds were those with $\mathrm{R}=\mathrm{Ph}-, \mathrm{NC}-, \mathrm{CH}_{3} \mathrm{CH}_{2} \mathrm{~S}-$ (unidentified phases), $\mathrm{CH}_{2}=\mathrm{CH}-\mathrm{COO}-(\mathrm{N}), \mathrm{CH}_{3} \mathrm{OCOO}-(\mathrm{N}), \mathrm{CH}_{3} \mathrm{CH}_{2} \mathrm{OCOO}-(\mathrm{N})$,

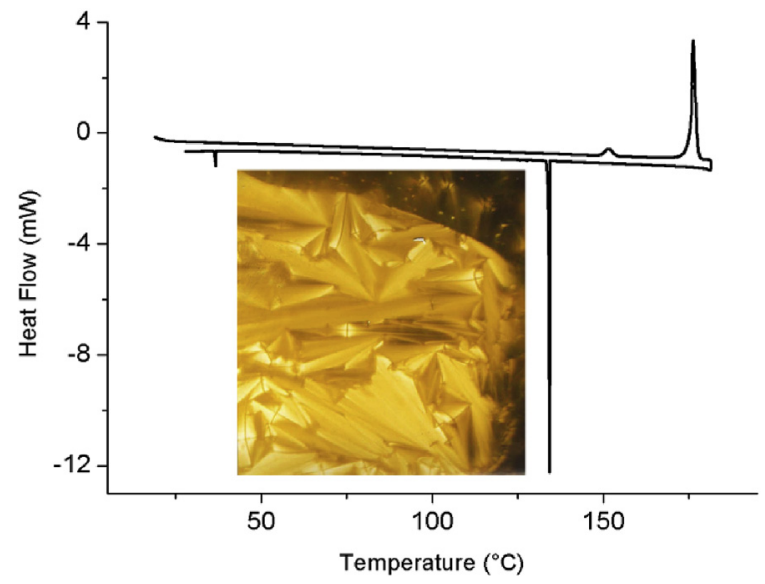

Fig. 7. DSC measurements for the Schiff base with the corresponding POM images. 
$\mathrm{CH}_{2} \mathrm{COO}-(\mathrm{N}), \mathrm{CH}_{3} \mathrm{O}-(\mathrm{N})$ and $\mathrm{CH}_{3} \mathrm{CH}_{2} \mathrm{O}-(\mathrm{N})$. Among the second group, only those in which $-\mathrm{R}=-\mathrm{OCH}_{3}(\mathrm{~N}),-\mathrm{OCH}_{2} \mathrm{CH}_{3}(\mathrm{~N}),-\mathrm{CH}=$ $\mathrm{CH}-\mathrm{COOCH}_{2} \mathrm{CH}\left(\mathrm{CH}_{3}\right)_{2}(\mathrm{Sm}),-\mathrm{COO}-\mathrm{Ph}-\mathrm{X}$ for $\mathrm{X}=\mathrm{Br}, \mathrm{CN}$, and $\mathrm{CH}_{3}$ $(\mathrm{N})$ were mesogenic.

The absence of a mesogenic character for most of this kind of compounds deprived from long terminal chains agrees with the ordered character of the SmB mesophase detected for our compound. It bears very short aliphatic groups in both extremes, but the number of terminal methyl groups and the nature of the functional groups they are attached to, seem to be just enough to warrant its mesogenic character-very likely as a delicate balance of geometry anisotropy [56], axial and lateral interactions [27,57] which manifest in a hexatic SmB phase.

\section{Conclusions}

The synthesis of the Schiff base 4-(4-dimethylaminobenzylidene) aminoacetophenone was achieved by the reaction between 4(dimethylamino) benzaldehyde and 4-aminoacetophenone in ethanol. The product was characterized by IR, Raman, UV-Vis, ${ }^{1} \mathrm{H}$ and ${ }^{13} \mathrm{C}$ NMR and fluorescence spectroscopy. To support the interpretation of the experimental results, the analysis was complemented with quantum chemical calculations at B3LYP method and different basis sets. The crystal structure was determined by means of single-crystal X-ray diffraction methods. This compound crystallizes in the triclinic $P$ - 1 space group with $a=9.9357(4) \AA$ $b=17.1016(9) \AA, c=18.1945(9) \AA, \alpha=78.347(4)^{\circ}, \beta=77.169(4)^{\circ}$, $\gamma=76.996(4)^{\circ}$, and $Z=8$ molecules per unit cell. The crystallographic data reveals that there are four independent molecules per asymmetric unit that mainly differ from one another in rotations around the $\sigma$-bond of the azomethine $\mathrm{N}$-atom with the phenyl ring, hence reflecting the conformational degree of freedom of the molecule. The Hirshfeld surfaces and fingerprint plots were an important tool in the analysis of the intermolecular interactions and their quantitative contributions to the crystal packing of the Schiff base. These results indicate that the $\mathrm{H} \cdots \mathrm{H}$ contributions are more remarkable than other contacts. The crystal packing showed noticeably stabilized by non-conventional $\mathrm{C}-\mathrm{H} \cdots \mathrm{O}, \mathrm{C}-\mathrm{H} \cdots \mathrm{N}$ and $\mathrm{C}-\mathrm{H} \cdots \mathrm{C}$ hydrogen bonds and no $\pi-\pi$ stacking interactions were observed. The substance is thermally stable up to $250{ }^{\circ} \mathrm{C}$, and the vibration and electronic properties of the substance were fully determined and supported by quantum chemical calculations. The Fluorescence spectrum of the molecule provided measurable signals when irradiated with $\lambda_{\text {exc. }}=430 \mathrm{~nm}$. The formation of dimers proposed due to intermolecular interactions, when Schiff base concentration was increased, is consistent with the short contacts found in the crystal packing, and seems also in line with the detected hexatic SmB mesophase.

\section{Acknowledgements}

This work was supported by CONICET (PIP 1529, PIP 0205, and PIP 0359), ANPCyT (PME06 2804, PICT06 2315, and PICT-20130697), CIUNT (Project D542/2), UNLP (Project 11X/683), and UNLu of Argentina (Project 14/B152). SEU thanks Deutscher Akademischer Austauschdienst Germany (DAAD) for an equipment grant and financial support. M.R. and A.D.S. thank CONICET for doctoral fellowships.

\section{Appendix A. Supplementary information}

Supplementary information related to this article can be found at http://dx.doi.org/10.1016/j.molstruc.2016.11.071.

\section{References}

[1] H. Schiff, H. Schiff, Mitteilungen aus dem universitatslaboratorium in Pisa: eineneue reihe organischer basen, Justus Liebigs Ann. Chem. 131 (1864) 118

[2] D.N. Dhar, C.L. Taploo, Schiff bases and their applications, J. Sci. Ind. Res. 41 (1982) 501.

[3] P. Przybylski, A. Huczynski, K. Pyta, B. Brzezinski, F. Bartl, Biological properties of schiff bases and azo derivatives of phenols, Curr. Org. Chem. 13 (2009) 124

[4] G. Bringmann, M. Dreyer, J.H. Faber, P.W. Dalsgaard, D. Staerk, J.W. Jaroszewski, Ancistrotanzanine C and related 5,1'- and 7,3'-coupled naphthylisoquinoline alkaloids from Ancistrocladus tanzaniensis, J. Nat. Prod. 67 (2004) 743.

[5] J. Salimon, N. Salih, H. Ibraheem, E. Yousief, Synthesis of 2-N-salicylidene-5(substituted)-1,3,4-thiadiazole as potential antimicrobial agents, Asian J. Chem. 22 (2010) 5289.

[6] Z. Guo, R. Xing, S. Liu, Z. Zhong, X. Ji, L. Wang, Antifungal properties of Schiff bases of chitosan, N-substituted chitosan and quaternized chitosan, Carbohydr. Res. 342 (2007) 1329.

[7] I. Danaee, O. Ghasemi, G.R. Rashed, M. Rashvand Avei, M.H. Maddahy, Effect of hydroxyl group position on adsorption behavior and corrosion inhibition of hydroxybenzaldehyde Schiff bases: electrochemical and quantum calculations Original Research Article, J. Mol. Struct. 1035 (2013) 247.

[8] R. Drozdzak, B. Allaert, N. Ledoux, I. Dragutan, R. Verport, Ruthenium complexes bearing bidentate Schiff-base ligands as efficient catalysts for organic and polymer synthesis, Coord. Chem. Rev. 249 (2005) 3055.

[9] C.T. Zeyrek, A. Elmali, Y. Elerman, Synthesis and crystal structures of a new $\mu-$ Bis(tetradentate) schiff base ligand and its mononuclear iron(III) complex: iron(III) induced imidazolidine ring hydrolysis of binucleating schiff base ligand, Z. Naturforsch 60b (2005) 520.

[10] A.E. Taggi, A.M. Hafez, H. Wack, B. Young, D. Ferraris, T. Lectka, The development of the first catalyzed reaction of ketenes and imines: catalytic, asymmetric synthesis of $\beta$-lactams, J. Am. Chem. Soc. 124 (2002) 6626.

[11] R. Ramnauth, S. Al-Juaid, M. Motevalli, B.C. Parkin, A.C. Sullivan, Synthesis, structure, and catalytic oxidation chemistry from the first Oxo-Imido schiff base metal complexes, Inorg. Chem. 43 (2004) 4072.

[12] A.P. Mishra, P. Gupta, Effect of chelation on therapeutic potential of drugs: synthesis, structure, antimicrobial and insecticidal activity of 3d-metal complexes involving Schiff-bases, J. Chem. Pharm. Res. 3 (2011) 150.

[13] I. Anis, M. Aslam, Z. Noreen, N. Afza, A. Hussain, A.H. chaudhry, M. safder, A review (part B) - use of schiff base transition metal complexes as a catalyst,, Int. J. Curr. Pharm. Res. 5 (2013) 30.

[14] S. Alexander, V. Udayakumar, V. Gayathri, Hydrogenation of olefins by polymer-bound palladium(II) Schiff base catalyst, J. Mol. Catal. A - Chem. 314 (2009) 21.

[15] S. Pu, Z. Tong, G. Liu, R. Wang, Multi-addressable molecular switches based on a new diarylethene salicylal Schiff base derivative, J. Mater. Chem. C 1 (2013) 4726.

[16] O.A.M. Ali, L.H. Abdel-Rahman, R.M. Ramadan, Ruthenium carbonyl derivatives of N-salicylidene-2-hydroxyaniline Schiff base, J. Coord. Chem. 60 (2007) 2335.

[17] M.I. Khan, A. Khan, I. Hussain, M.A. Khan, S. Gul, M. Iqbal, I. Ur-Rahman, F. Khuda, Spectral, XRD, SEM and biological properties of new mononuclear Schiff base transition metal complexes, Inorg. Chem. Commun. 35 (2013) 104.

[18] S. Leela, R. Hema, H. Stoeckli-Evans, K. Ramamurthi, G. Bhagavannarayana, Design, synthesis, growth and characterization of 4-methoxy-4'-dimethylamino-benzylidene aniline (MDMABA): a novel third order nonlinear optical material, Spectrochim. Acta A 77 (2010) 927.

[19] C.T. Zeyrek, G. Alpaslam, H. Alyar, M. Yildiz, N. Dilek, H. Ünver, Synthesis, molecular structure, spectroscopic and theoretical studies on E-2-ethoxy-4[(4-ethoxyphenylimino) methyl] pheno, J. Mol. Struct. 1088 (2015) 14.

[20] S. Leela, K. Ramamurthi, G. Bhagavannarayana, Synthesis, growth, spectral, thermal, mechanical and optical properties of 4-chloro-4'dimethylaminobenzylidene aniline crystal: a third order nonlinear optical material, Spectrochim. Acta A 74 (2009) 78.

[21] A. Subashini, R. Kumaravel, S. Leela, H.S. Evans, D. Sastikumar, K. Ramamurthi, Synthesis, growth and characterization of 4-bromo-4'chloro benzylidene aniline - a third order non linear optical material, Spectrochim. Acta A 78 (2011) 935.

[22] S. Pathak, A. Kumar, P. Tandon, Molecular structure and vibrational spectroscopic investigation of 4-chloro-4'dimethylamino-benzylidene aniline using density functional theory, J. Mol. Struct. 981 (2010) 1.

[23] Z. Fang, F. Wu, B. Yi, C. Cao, X. Xie, Effects of molecular conformation on the spectroscopic properties of 4,4'-disubstituted benzylideneanilines, J. Mol, Struct. 1104 (2016) 52

[24] P.J. Collings, M. Hird, Introduction to Liquid Crystals: Chemistry and Physics, Taylor \& Francis Ltd., U.K., 1998.

[25] D. Demus, J. Goodby, G.W. Gray, H.W. Spiess, V. Vill, Handbook of Liquid Crystals, Wiley- VCH, Weinheim, 1998.

[26] B. Donio, D. Guillon, R. Deschenaux, D.W. Bruce, J. McCleverty, T.J. Meyer, Comprehensive Coordination Chemistry, Elsevier Pergamon, Amsterdam, 2004.

[27] S.T. Ha, L.K. Ong, J.P. Wong, G.Y. Yeap, H.C. Lin, S.T. Ong, T.M. Koh, Mesogenic Schiff's base ether with dimethylamino end group, Phase Transitions 82 (2009) 387. 
[28] S.T. Ha, L.K. Ong, S.T. Ong, G.Y. Yeap, J.P.W. Wong, T.M. Koh, H.C. Lin, Synthesis and mesomorphic properties of new Schiff base esters with different alkyl chains, Chin. Chem. Lett. 20 (2009) 767.

[29] CrysAlisPro, Oxford Diffraction Ltd., version 1.171.33.48 (release 15-09-2009 CrysAlis171.NET).

[30] G.M. Sheldrick, A short history of SHELX, Acta Crystallogr. A 64 (2008) 112.

[31] G.M. Sheldrick, Crystal structure refinement with SHELX, Acta Cryst. A 71 (2015) 3.

[32] M.J. Frisch, J.A. Pople, J.S. Binkley, J. Chem. Phys. 80 (1984) 3265;

a) M.J. Frisch, G.W. Trucks, H.B. Schlegel, G.E. Scuseria, M.A. Robb, J.R. Cheeseman, J.A. Montgomery Jr., T. Vreven, K.N. Kudin, J.C. Burant, J.M. Millam, S.S. Iyengar, J. Tomasi, V. Barone, B. Mennucci, M. Cossi, G. Scalmani, N. Rega, G.A. Petersson, H. Nakatsuji, M. Hada, M. Ehara, K. Toyota, R. Fukuda, J. Hasegawa, M. Ishida, T. Nakajima, Y. Honda, O. Kitao, H. Nakai, M. Klene, X. Li, J.E. Knox, H.P. Hratchian, J.B. Cross, C. Adamo, J. Jaramillo, R. Gomperts, R.E. Stratmann, O. Yazyev, A.J. Austin, R. Cammi, C. Pomelli, J.W. Ochterski, P.Y. Ayala, K. Morokuma, G.A. Voth, P. Salvador, J.J. Dannenberg, V.G. Zakrzewski, S. Dapprich, A.D. Daniels, M.C. Strain, O. Farkas, D.K. Malick, A.D. Rabuck, K. Raghavachari, J.B. Foresman, J.V. Ortiz, Q. Cui, A.G. Baboul, S. Clifford, J. Cioslowski, B.B. Stefanov, G. Liu, A. Liashenko, P. Piskorz, I. Komaromi, R.L. Martin, D.J. Fox, T. Keith, M.A. Al-Laham, C.Y. Peng, A. Nanayakkara, M. Challacombe, P.M.W. Gill, B. Johnson, W. Chen, M.W. Wong, C. González, J.A. Pople, Gaussian 03, Revision C.02, Gaussian, Inc, Wallingford, CT, 2004.

[33] A.D. Becke, Density-functional thermochemistry. III. The role of exact exchange, J. Chem. Phys. 98 (1993) 5648.

[34] C. Lee, W. Yang, R.G. Parr, Development of the Colle-Salvetti correlation-energy formula into a functional of the electron density, Phys. Rev. B 37 (1988) 785.

[35] M.H. Jamróz, Vibrational energy distribution analysis (VEDA): scopes and limitations, Spectrochim. Acta A 114 (2013) 220.

[36] M.H. Jamróz, Vibrational Energy Distribution Analysis VEDA4, Warsaw, 2004.

[37] P. Elliot, F. Furche, K. Burke, Rev. Comp. Chem. 26 (2009) 91.

[38] J.R. Cheeseman, G.W. Trucks, T.A. Keith, M.J. Frisch, A comparison of models for calculating nuclear magnetic resonance shielding tensors, Chem. Phys. 104 (1996) 5497.

[39] S.K. Wolf, D.J. Grimwood, J.J. McKinnon, M.J. Turner, D. Jayatilaka, M.A. Spackman, CrystalExplorer (Version 3.1), University of Western Austalia, 2012.

[40] M.A. Spackman, D. Jayatilaka, Hirshfeld surface analysis, CrystEngComm 11 (2009) 19.

[41] M.A. Spackman, J.J. McKinnon, Fingerprinting intermolecular interactions in molecular crystals, CrystEngComm 4 (2002) 378

[42] M.A. Spackman, Molecules in crystals, Phys. Scr. 87 (2013) 048103.

[43] H.S. Yathirajan, A.M. Vijesh, B. Narayana, B.K. Sarojini, M. Bolte, 1-(4-\{[(E)-(4-
Diethylamino)-2-hydroxyphenyl)-methylene]amino\}phenyl)ethanone, Acta Cryst. E63 (2007) 0936.

[44] M. Rocha, A. Di Santo, J.M. Arias, D.M. Gil, A. Ben Altabef, Ab-initio and DFT calculations on molecular structure, NBO, HOMO-LUMO study and a new vibrational analysis of 4-(Dimethylamino) Benzaldehyde, Spectrochim. Acta A 136 (2015) 635.

[45] E. Lizarrága, D.M. Gil, G.A. Echeverría, O.E. Piro, C.A.N. Catalán, A. Ben Altabef, Synthesis, crystal structure, conformational and vibrational properties of 6 acetyl-2,2-dimethyl-chromane, Spectrochim. Acta A 127 (2014) 74.

[46] M. Toy, H. Tanak, Molecular structure and vibrational and chemical shift assignments of 3'-chloro-4-dimethylamino azobenzene by DFT calculations Spectrochim. Acta A 152 (2016) 530.

[47] R.M. Ramadan, K.A. Al-Nasr, A.F.H. Noureldeen, Synthesis, spectroscopic studies, antimicrobial activities and antitumor of a new monodentate $\mathrm{V}$ shaped Schiff base and its transition metal complexes, Spectrochim. Acta A 132 (2014) 417.

[48] M.I. Khan, A. Khan, I. Hussain, M.A. Khan, S. Gul, M. Iqbal, I.U. Rahman, F. Khuda, Spectral, XRD, SEM and biological properties of new mononuclear Schiff base transition metal complexes, Inorg. Chem. Commun. 35 (2013) 104

[49] M.K Subramanian, P.M. Anbarasan, V. Ilangovan, S. Moorthy Babu, FT-IR, NIRFT-Raman and gas phase infrared spectra of 3-aminoacetophenone by density functional theory and ab initio Hartree-Fock calculations, Spectrochim. Acta A 71 (2008) 59.

[50] S. Pathak, A. Kumar, P. Tandon, Molecular structure and vibrational spectroscopic investigation of 4-chloro-4'dimethylamino-benzylidene aniline using density functional theory, J. Mol. Struct. 981 (2010) 1.

[51] V. Arjunan, M. Kalaivani, S. Senthilkumari, S. Mohan, Vibrational, NMR and quantum chemical investigations of acetoacetanilde, 2-chloroacetoacetanilide and 2-methylacetoacetanilide,, Spectrochim. Acta A 115 (2013) 154.

[52] S. Leela, R. Hema, H. Stoeckli-Evans, K. Ramamurthi, G. Bhagavannarayana, Design, synthesis, growth and characterization of 4-methoxy-4'-dimethylamino-benzylidene aniline (MDMABA): a novel third order nonlinear optica material, Spectrochim. Acta A 77 (2010) 927.

[53] L.A. Kutulya, V.F. Morina, Shevchenko, B.M. Krasovitskll, Spectroluminescen properties of azomethine derivatives of 1-(4-formylphenyl)-3-aryl-5-phenyl2-pyrazolines, J. Appl. Spectrosc. 31 (1979) 1491.

54] I. Dierking, Textures of Liquid Crystals, Wiley-VCH, Weinheim, 2003.

[55] LiqCryst5.1.43, V. Vill, G. Peters, S. Thiemann (Eds.), LCI Publisher GmbH. www.lci-publisher.com/.

[56] D. Demus, One hundred years of liquid-crystal chemistry: thermotropic liquid crystals with conventional and unconventional molecular structure, Liq. Cryst. 5 (1989) 75

[57] J.A. Castellano, J.E. Goldmacher, L.A. Barton, J.S. Kane, Liquid crystals.II. Effects of terminal group substitution on the mesomorphic behavior of some benzylideneanilines, J. Org. Chem. 33 (1968) 3501. 